\title{
The Brno Batholith: an insight into the magmatic and metamorphic evolution of the Cadomian Brunovistulian Unit, eastern margin of the Bohemian Massif
}

\author{
Jaromír LEICHMANN ${ }^{1, *}$, Volker HÖCK² \\ ${ }^{1}$ Department of Geological Sciences, Faculty of Science, Masaryk University Brno, Kotlářská 2, 611 37 Brno; leichman@sci.muni.cz \\ ${ }^{2}$ Fachbereich Geographie, Geologie und Mineralogie der Universität Salzburg, Hellbrunnerstrasse 34/III, A-5020 Salzburg, Austria \\ ${ }^{*}$ Corresponding author
}

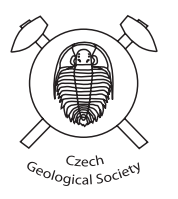

The Brno Batholith, a part of the larger Brunovistulian Unit, consists of three genetically independent complexes - Western Granitoid Complex (part of the Thaya Terrane), Ophiolite Belt (formerly Metabasite Zone or Central Basic Belt), and Eastern Granitoid Complex (part of the Slavkov Terrane). The field with geochronological evidence indicate younger age of both granitoid complexes compared with the ophiolite.

The composition of the Eastern Granitoid Complex (not newly studied in this paper) points to a relatively primitive Cadomian volcanic-arc environment. The Ophiolite Belt comprises a tilted segment of an almost complete metamorphosed ophiolite sequence with lithologically and geochemically obvious suprasubduction signature. Three main granite suites, with distinct S-, I-, and A-type affinities, are exposed in the Western Granitoid Complex. Abundance of crustal xenoliths, complex morphological zircon population, overall S-type chemistry, as well as geophysical and petrological evidence for basalt underplating, all point to the origin of the Tetčice suite via melting of the older metasedimentary crust. The Rena suite consists of I-type volcanic-arc granodiorites to granites, whereas small intrusions of granites with certain A-type affinity are characteristic of the Hlína suite. Equivalents of all three suits were recognized in the northern part of the Dyje Batholith, which represents the direct continuation of the western branch of the Brno Batholith.

The geological structure and geochronological data from both the Brno and Dyje batholiths exhibit some similarities with those documented in the Eastern Desert in Egypt. This may indicate a probable Gondwana affinity to the whole Brunovistulian assembly.

Keywords: Brno Batholith, Brunovistulicum, granites, ophiolites, Gondwana, petrology

Received: 22 October 2008; accepted 9 January 2009; handling editor: E. Jelinek

\section{Introduction}

The aim of this paper is new petrologic characterization and geological interpretation of the Brno Batholith. This paper deals mainly with mafic rocks from the Metabasite Zone, and granites from the Western Granitoid. The position of Brno Batholith in the Brunovistulian Complex Unit as well as its relation to the southern Dyje Massif, and magmatic evolution of the whole Brunovistulicum are discussed.

The easternmost margin of the Bohemian Massif on the Austrian, Czech, and Polish territories, approximately between the Danube and the Odra rivers, is built up of a complex of metamorphic and magmatic rocks called Brunovistulicum by Dudek (1980) or the Brunovistulian Complex by Jelínek and Dudek (1993). The most important outcrops of Brunovistulicum are the Dyje (Thaya) Batholith (Finger et al. 1995, 2000a) or Dyje Massif in the Czech literature (e.g. Štelcl and Weiss 1986), between Krems and Znojmo at the Czech-Austrian border; the Brno Batholith (Leichmann 1996; Hanžl and Melichar 1997; Kalvoda et al. 2008), or Brno Massif (Štelcl and
Weiss 1986) in the vicinity of Brno (Fig. 1); and the Desná Gneiss (Fišera and Patočka 1989) in the Jeseníky Mountains (N Moravia). The term 'batholith' is preferred here, as the term 'massif' has not been used in the English publications for large granitic bodies recently (see Best and Christiansen 2001). The eastern part of the Brunovistulicum, which was not reactivated during the Variscan orogeny, acted as a stable foreland for both the Variscan and the Alpine fold belts. In the west, the Moravicum as the western Variscan mobile part was thrust onto non-mobilized part of the Brunovistulicum, and in turn concealed under the Moldanubian nappes. In the East, the Brunovistulicum, together with its sedimentary cover, is covered by the Carpathian nappes. The buried eastern part is known from deep drillings, and was described by Dirnhofer (1996) with Riegler (2000) in Austria, Jelínek and Dudek (1993) with Finger et al. (2000a) in the Czech Republic, and by Żelaźniewicz et al. (1997, 2001 and citations therein) in Poland. The Brunovistulicum consists of low- to high-grade metamorphic rocks (Höck 1975; Dudek 1980; Stelcl and Weiss 1986; Finger et al 2000a) and several types of magmatic rocks, rang- 
ing from ultramafic to very acid rhyolites (Leichmann 1996). Jelínek and Dudek (1993) interpreted the whole magmatic Brunovistulian assembly, based mostly on the geochemical data from the covered part of this unit, as being comagmatic. The most widespread, well-preserved, and remarkable surface exposure of the Brunovistulian Complex is the Brno Batholith. A comparison with the other exposed and covered parts of Brunovistulicum shows that the composition and architecture in the Brno Batholith is of crucial importance for the whole of Brunovistulicum and its correct interpretation.

\section{Geological setting}

The Brno Batholith exhibits a complex internal structure and evolutionary history. It extends over $70 \mathrm{~km}$ in the S$\mathrm{N}$ direction between Miroslav in the South and Boskovice in the North. Brno is situated in central part towards the E (Fig. 2). In the West the Brno Batholith is off cut by the eastern marginal fault of the Boskovice Furrow. In the East it is covered partly by Tertiary and Quaternary, and partly in contact with Devonian and Carboniferous sediments. It can be subdivided into three parts (com-

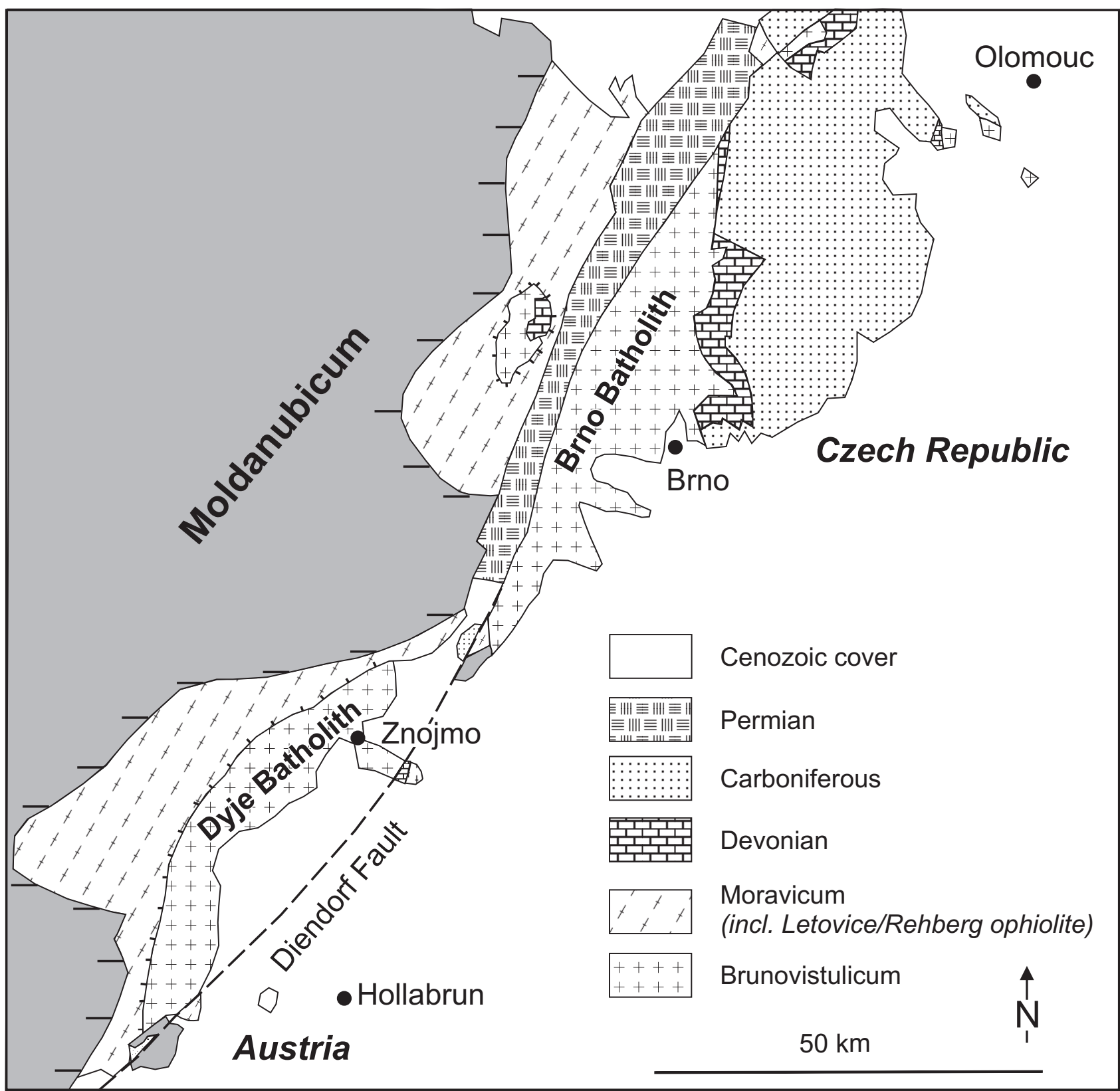

Fig. 1 Simplified map of the eastern margin of the Bohemian Massif. 


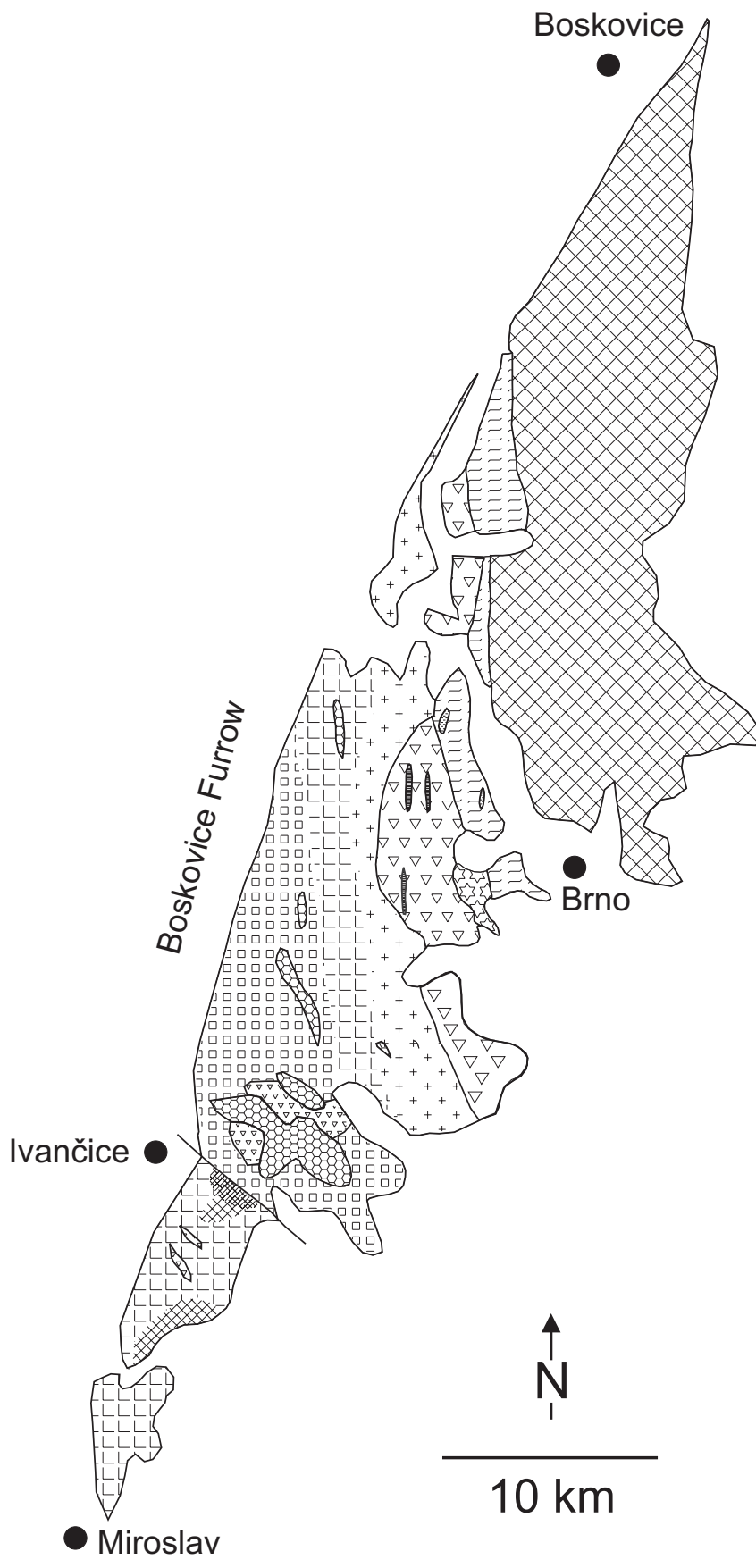

Fig. 2 Geological sketch map of the Brno Batholith.

plexes) separated by steep boundaries (Štelcl and Weiss 1986, Fig. 2). The Western Granitoid Complex consists of granites, granodiorites, and diorites, which intruded highly metamorphosed gneisses, amphibolites, and calc silicates schists. The central part, Metabasite Zone in the older Czech literature, is chiefly an assemblage of mafic plutonic and volcanic rocks; and the Eastern Granitoid Complex is built by granodiorites, tonalites, and quartz diorites. The Metabasite Zone is cut by granitoids of the

\section{Eastern Granitoid Complex}

12 quartz diorites, tonalites, granodiorites

\section{Metabasite Zone}

\begin{tabular}{|c|c|}
\hline & felsic volcanic rocks \\
\hline & basalts \\
\hline 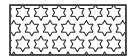 & trondhjemites \\
\hline $\begin{array}{l}\nabla \nabla \nabla \nabla \nabla \nabla \\
P \nabla \nabla \nabla \nabla \nabla \\
\nabla \nabla \nabla \nabla \nabla \nabla\end{array}$ & diorites and gabbros \\
\hline & ultramafic rocks \\
\hline
\end{tabular}

\section{Western Granitoid Complex}

\begin{tabular}{|c|c|}
\hline 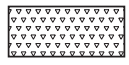 & garnet-bearing leucogranites, Hlína suite \\
\hline & red granites, Tetčice suite \\
\hline 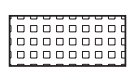 & $\begin{array}{l}\text { fine-grained, grey biotite granodiorites } \\
\text { (Tetčice suite) }\end{array}$ \\
\hline & transition zone between red and grey granites \\
\hline & diorites (Tetčice suite) \\
\hline & amphibole-biotite granodiorites, Rena suite \\
\hline & biotite granites-granodiorites (Rena suite) \\
\hline
\end{tabular}

both complexes (Leichmann 1996). The primary intrusion contacts were strongly tectonically overprinted mainly during the Variscan orogeny (Melichar 1995).

Age dating confirms the observed relation between these units. Finger et al. (2000b) reported a $\mathrm{Pb}-\mathrm{Pb}$ zircon evaporation age of $725 \pm 15 \mathrm{Ma}$ from rhyolites crosscutting the metabasalts of the Metabasite Zone, indicating a minimum age of this presumed ophiolite complex. This age contrasts with these reported from granitoids of the western and eastern complexes. Several geochronological data were reported from both granitoid complexes. An ${ }^{40} \mathrm{Ar} /{ }^{39} \mathrm{Ar}$ amphibole dating from the eastern part yielded an age of $596.1 \pm 2.1 \mathrm{Ma}$ (Dallmeyer et al. 1994). From the western part are known two ages for the diorites; a U$\mathrm{Pb}$ zircon age of $584 \pm 5 \mathrm{Ma}$ (van Breemen et al. 1982) is very close to an ${ }^{40} \mathrm{Ar} /{ }^{39} \mathrm{Ar}$ age determination on amphibole of $586.9 \pm 0.5 \mathrm{Ma}$ (Dallmeyer et al. 1994).

In the following chapters we will concentrate on the Metabasite Zone and the granites of the Western Granitoid Complex. Regarding the Eastern Granitoid Complex 
we will refer only to published data (Štelcl and Weiss 1986; Jelínek and Dudek 1993; Hanžl 1994; Hanžl and Melichar 1997; Finger et al. 2000a).

\section{Methods}

Whole-rock major-element and mineral analyses were carried out by means of an electron microprobe (EMP, type JEOL 8600, at University of Salzburg). The glass pellets (for EMP) and polished thin-sections were measured at $15 \mathrm{kV}$ and $50 \mathrm{nA}$. Glass pellets were prepared from melted rocks with addition of lithium borate; five points were measured on each pellet. Major elements were corrected according to the ZAF method.

Trace elements were determined on powder pellets using Philips PW 1400 XRF (University of Salzburg) at $45 \mathrm{kV} / 60 \mathrm{~mA}$. Zircons were separated according to the method described by Frasl (1963), their morphology was evaluated according to Pupin (1980). The REE were determined at the Acme Chemical Laboratories Ltd, Vancouver, by ICP-MS. See http://www.acmelab.com for analytical details.

\section{Results}

\subsection{Metabasite Zone}

The Metabasite Zone (Štelcl and Weiss 1986) or Central Basic Belt (Finger et al. 2000a) is situated between the two granitoid parts, and constitutes a $27 \mathrm{~km}$ long and maximally $8 \mathrm{~km}$ wide belt. This zone is divided, based on the lithology, in two sequences - (a) plutonic and (b) volcanic. The former consists of four rock types (ultramafic rocks, amphibole-bearing diorites, gabbros, and trondhjemites - Leichmann 1994), and the later of two rock assemblages - basalts and bimodal association of dolerites with rhyolites.

The whole complex dips to the east. Therefore the plutonic rocks crop out preferentially in the West, while the volcanic sequence is found in the East, of the Metabasite Zone. The Zone is marked by a distinct positive gravity anomaly (Geofyzika 2000).

Apart from the rock types listed above, younger discordant intrusions of fine-grained granites to rhyolites belonging of the granitoid complexes, Silurian basaltic (Přichystal 1999), and Variscan lamprophyric dykes (Šmejkal 1964), were mapped in this belt.

\subsubsection{Plutonic sequence}

The ultramafic rocks form small - max. $50 \mathrm{~m}$ thick and $400 \mathrm{~m}$ long - elongated lenses and layers in the gabbros and diorites. Their present-day mineralogy is of metamorphic origin. The ultramafic rocks are not homogenous; several types could be distinguished based on their mineralogical and chemical compositions (Sulovský 1975; Gregerová 1982; Leichmann 1996). The rocks could be classified, based on CIPW normative compositions, as dunites and harzburgites consisting mainly of serpentine, talk, chlorite and iron oxides, whereas green amphibole, chlorite, and iron oxides are major components in the olivine websterites.

Diorites and gabbros are the most widespread rocks in the plutonic sequence. Diorites strongly prevail over gabbros. Cumulate- as well as pegmatite-like structures (with up to $12 \mathrm{~cm}$ long amphiboles) are observed within the gabbros, partly alternating with layers of former websterites.

The modal composition with variably zoned plagioclase (Tab. 1), amphibole (Tab. 2, Fig. 3), zoisite, chlorite, epidote, carbonate, white mica, $\mathrm{Fe} / \mathrm{Ti}$ oxides, and rarely quartz imply a complex metamorphic overprinting (see below for details). Due to the metamorphic overprinting, the original composition of plagioclases, necessary to distinguish between gabbros and diorites, is only rarely preserved. Tentatively we used instead the whole-rock geochemistry (Tab. 3). Two groups can be distinguished: one with higher $\mathrm{SiO}_{2}(51-53$ wt. \%) and low $\mathrm{MgO}(\sim 5 \%)$, and another more basic $\left(\mathrm{SiO}_{2} \sim 49 \%\right)$ with high $\mathrm{MgO}(\sim 20 \%)$ corresponding by their normative $\mathrm{Ab} / \mathrm{An}$ ratios to diorites and gabbros, respectively. Low concentrations of HFSE $\left(\mathrm{TiO}_{2}=0.72-0.84\right.$ wt. \%; $\mathrm{Zr}=7-24 \mathrm{ppm} ; \mathrm{Nb}=3-4 \mathrm{ppm}$ and $\mathrm{Y}=8-11 \mathrm{ppm})$, as well as of LILE $(\mathrm{Rb}=13-19 \mathrm{ppm} ; \mathrm{Sr}=438-558 \mathrm{ppm}$ and $\mathrm{Ba}=95-106)$ are typical of both diorites and gabbros. However, the concentrations of LILE, mainly Rb, as well as $\mathrm{K}\left(0.44-0.69\right.$ wt. $\left.\% \mathrm{~K}_{2} \mathrm{O}\right)$ might be elevated as a consequence of the later alteration (sericitization) of plagioclases.

Trondhjemites (Baker 1979) crop out at the boundary between the plutonic and volcanic sequences. They consist of plagioclase (52-66 vol. \%), ranging from $\mathrm{An}_{1}$ at the rims to the $\mathrm{An}_{30}$ in the cores (Tab. 1; points 26-29), quartz (25-43 vol. \%), relics of clinopyroxene, rarely K-feldspar (less than $1 \%$ ), secondary white mica, and chlorite (up to $9 \%$ ). The younger albite and white mica replace the original oscillatory-zoned plagioclase almost entirely. The clinopyroxene is nearly completely replaced by chlorite and $\mathrm{Fe}-\mathrm{Ti}$ oxides. The chemical composition (Tab. 3), with high $\mathrm{SiO}_{2}(72.8-74.5$ wt. \%), $\mathrm{Na}_{2} \mathrm{O}(4.4-4.5 \%)$, and low $\mathrm{CaO}(0.95-1.5 \%)$, with $\mathrm{FeO}_{\text {tot }}(1.4-2 \%)$ is in accord with their mineralogy. The unusually high concentration of $\mathrm{K}_{2} \mathrm{O}(0.83-1.3 \%)$, not typical of trondhjemites, is caused by later sericitization of plagioclase. Table 4 (analyses 7-10) shows four EMP analyses of the fine-grained muscovites replacing the 
Tab. 1 Electron microprobe analyses from plagioclase (wt. \% and apfu based on 8 O)

\begin{tabular}{|c|c|c|c|c|c|c|c|c|c|c|c|c|c|c|c|}
\hline Sample & 1 & 2 & 3 & 4 & 5 & 6 & 7 & 8 & 9 & 10 & 11 & 12 & 13 & 14 & 15 \\
\hline $\mathrm{SiO}_{2}$ & 57.69 & 62.11 & 60.54 & 66.88 & 64.87 & 62.99 & 62.25 & 67.63 & 55.53 & 55.68 & 58.20 & 57.53 & 68.19 & 67.79 & 66.56 \\
\hline $\mathrm{Al}_{2} \mathrm{O}_{3}$ & 26.01 & 23.46 & 24.09 & 20.48 & 21.86 & 23.16 & 23. & 19.68 & 28.06 & 27.96 & 26.19 & 26.99 & 19.61 & 19.60 & 19.99 \\
\hline $\mathrm{FeO}$ & 0.00 & 0.00 & 0.10 & 0.16 & 0.00 & 0.00 & 0.00 & 0.06 & 0.07 & 0.00 & 0.06 & 0.12 & 0.00 & 0.14 & 0.07 \\
\hline $\mathrm{CaO}$ & 8.17 & 4.74 & 4.93 & 1.18 & 2.81 & 4.45 & 4.93 & 0.60 & 10.38 & 10.20 & 8.26 & 8.82 & 0.14 & 0.30 & 0.88 \\
\hline $\mathrm{Na}_{2} \mathrm{O}$ & 6.58 & 8.70 & 7.94 & 10.47 & 9.85 & 8.69 & 8.61 & 11.18 & 5.66 & 5.83 & 6.82 & 6.49 & 11.35 & 11.05 & 10.82 \\
\hline $\mathrm{K}_{2} \mathrm{O}$ & 0.23 & 0.13 & 0.35 & 0.40 & 0.07 & 0.14 & 0.25 & 0.12 & 0.09 & 0.10 & 0.12 & 0.12 & 0.09 & 0.09 & 0.11 \\
\hline Total & 98.68 & 99.14 & 97.95 & 99.57 & 99.46 & 99.43 & 99.52 & 99.27 & 99.79 & 100.07 & 99.65 & 100.08 & 99.38 & 98.97 & 98.43 \\
\hline $\mathrm{Si}$ & 2.613 & 2.771 & 2.737 & 2.994 & 2.867 & 2.796 & 2.770 & 2.978 & 2.504 & 2.516 & 2.612 & 2.575 & 2.993 & 2.989 & 2.958 \\
\hline $\mathrm{Al}$ & 1.388 & 1.234 & 1.284 & 1.062 & 1.139 & 1.212 & 1.231 & 1.021 & 1.491 & 1.481 & 1.385 & 1.424 & 1.014 & 1.019 & 1.047 \\
\hline $\mathrm{Ca}$ & 0.396 & 0.277 & 0.239 & 0.056 & 0.133 & 0.212 & 0.235 & 0.028 & 0.502 & 0.491 & 0.397 & 0.423 & 0.007 & 0.014 & 0.042 \\
\hline $\mathrm{Na}$ & 0.578 & 0.753 & 0.696 & 0.893 & 0.844 & 0.748 & 0.743 & 0.955 & 0.495 & 0.508 & 0.593 & 0.563 & 0.966 & 0.945 & 0.932 \\
\hline $\mathrm{K}$ & 0.013 & 0.007 & 0.020 & 0.022 & 0.004 & 0.008 & 0.014 & 0.007 & 0.005 & 0.006 & 0.007 & 0.007 & 0.005 & 0.005 & 0.006 \\
\hline An & 0.401 & 0.230 & 0.250 & 0.057 & 0.136 & 0.219 & 0.237 & 0.029 & 0.501 & 0.489 & 0.398 & 0.426 & 0.007 & 0.015 & 0.043 \\
\hline $\mathrm{Ab}$ & 0.585 & 0.763 & 0.729 & 0.920 & 0.860 & 0.773 & 0.749 & 0.965 & 0.494 & 0.505 & 0.595 & 0.567 & 0.988 & 0.980 & 0.951 \\
\hline Or & 0.013 & 0.008 & 0.021 & 0.023 & 0.004 & 0.008 & 0.014 & 0.007 & 0.005 & 0.006 & 0.007 & 0.007 & 0.005 & 0.005 & 0.006 \\
\hline Sample & 16 & 17 & 18 & 19 & 20 & 21 & 22 & 23 & 24 & 25 & 26 & 27 & 28 & 29 & \\
\hline $\mathrm{SiO}_{2}$ & 66.19 & 63.90 & 64.30 & 65.40 & 65.40 & 50.45 & 49.72 & 65.42 & 61.77 & 59.67 & 60.43 & 60.62 & 68.87 & 68.10 & \\
\hline $\mathrm{Al}_{2} \mathrm{O}_{3}$ & 21.14 & 21.80 & 22 & 20.70 & 21 & 30.77 & 31.58 & 21.51 & 24.36 & 25.39 & 24.08 & 24.40 & 19.39 & 19.35 & \\
\hline $\mathrm{FeO}$ & 0.15 & 0.06 & 0.08 & 0.00 & 0.00 & 0.27 & 0.12 & 0.09 & 0.07 & 0.00 & 0.13 & 0.13 & 0.00 & 0.00 & \\
\hline $\mathrm{CaO}$ & 1.69 & 3.04 & 3.06 & 1.73 & 2.20 & 14.32 & 14.65 & 2.58 & 3.78 & 7.39 & 6.22 & 6.14 & 0.08 & 0.18 & \\
\hline $\mathrm{Na}_{2} \mathrm{O}$ & 10.06 & 9.40 & 9.80 & 10.40 & 10.10 & 3.65 & 3.22 & 10.16 & 8.40 & 7.40 & 7.99 & 7.83 & 11.64 & 11.43 & \\
\hline $\mathrm{K}_{2} \mathrm{O}$ & 0.41 & 0.40 & 0.29 & 0.12 & 0.06 & 0.04 & 0 & 0.08 & 0.94 & 0.06 & 0.24 & 0.31 & 0.05 & 0.07 & \\
\hline Total & 99.64 & 98.60 & 99.53 & 98.35 & 98.76 & 99.51 & 99.29 & 99.84 & 99.31 & 99.89 & 99.09 & 99.44 & 100.00 & 99.13 & \\
\hline $\mathrm{Si}$ & 2.914 & 2.856 & 2.849 & 2.916 & 2.905 & 2.314 & 2.283 & 2.882 & 2.754 & 2.662 & 2.715 & 2.711 & 3.004 & 2.998 & \\
\hline $\mathrm{Al}$ & 1.097 & 1.148 & 1.149 & 1.088 & 1.099 & 1.663 & 1.709 & 1.117 & 1.280 & 1.335 & 1.275 & 1.286 & 0.997 & 1.004 & \\
\hline $\mathrm{Ca}$ & 0.080 & 0.146 & 0.145 & 0.083 & 0.105 & 0.704 & 0.721 & 0.122 & 0.180 & 0.353 & 0.299 & 0.294 & 0.004 & 0.009 & \\
\hline $\mathrm{Na}$ & 0.859 & 0.814 & 0.842 & 0.899 & 0.870 & 0.325 & 0.287 & 0.868 & 0.726 & 0.640 & 0.696 & 0.679 & 0.985 & 0.975 & \\
\hline $\mathrm{K}$ & 0.023 & 0.023 & 0.016 & 0.007 & 0.003 & 0.003 & 0 & 0.004 & 0.054 & 0.004 & 0.014 & 0.018 & 0.003 & 0.004 & \\
\hline An & 0.083 & 0.148 & 0.145 & 0.084 & 0.107 & 0.683 & 0.715 & 0.122 & 0.188 & 0.354 & 0.297 & 0.297 & 0.004 & 0.009 & \\
\hline $\mathrm{Ab}$ & 0.893 & 0.829 & 0.839 & 0.909 & 0.889 & 0.315 & 0.285 & 0.873 & 0.756 & 0.642 & 0.690 & 0.685 & 0.994 & 0.987 & \\
\hline Or & 0.024 & 0.023 & 0.016 & 0.007 & 0.003 & 0.002 & 0 & 0.005 & 0.056 & 0.004 & 0.014 & 0.018 & 0.003 & 0.004 & \\
\hline
\end{tabular}

Nr. 1-4; J/10/93 amphibole-biotite granodiorite (Rena suite): 1 core; 2 medium zone; 3 rim; 4 albitic rim

Nr. 5-8; J/5/93 fine-grained, grey biotite granodiorite (Tetčice suite): 5 altered core; 6-7 medium zone; 8 albitic rim

Nr. 9-12; J/14b/93 biotite-amphibole diorites: 9-10 core; 11-12 rim

Nr. 13-16; J/23/93 red granites (Tetčice suite): 13-14 albite appearing together with white mica; $15-16$ irregular layers of slightly more calcic albite in previous type

Nr. 17-20; J/21/93 garnet-bearing leucogranites: 17-18 core; 19-20 rim

Nr. 21-25; diorites, plutonic complex (Ophiolite Belt): 21-22 core; 23-24 rim; 25 transition core-rim

Nr. 26-29; trondhjemites, plutonic complex (Ophiolite Belt): 26-27 core; 28-29 rim

plagioclase. They are rich in $\mathrm{K}_{2} \mathrm{O}(10.3-10.4$ wt. \%) and $\mathrm{Al}_{2} \mathrm{O}_{3}(31-31.6 \%$ ), but poor in $\mathrm{CaO}$ (max. 0.08 wt. \%) and $\mathrm{Na}_{2} \mathrm{O}$ (up to 0.20 wt. \%). As the later crystallization of white mica is affecting the whole area, the potassium enrichment is probably a secondary feature, possibly connected to the intrusion of younger granites. Apart from disturbed $\mathrm{K}$ contents, the low concentrations of LILE ( $\mathrm{Rb}$ $=15-25 \mathrm{ppm}, \mathrm{Sr}=264-295 \mathrm{ppm})$, as well as those of the
HFSE $(\mathrm{Nb}=5-7 \mathrm{ppm}, \mathrm{Zr}=80-295 \mathrm{ppm}, \mathrm{Y}=9-10 \mathrm{ppm}$, $\mathrm{Ti}=840-1619$ ppm, Tab. 3) are noticeable.

\subsubsection{Volcanic sequence}

In the volcanic sequence were recognized dolerites, pillow lavas, massive lava flows as well as tuffs. Petrological and geochemical studies indicate a bimodal volcanism. 
Tab. 2 Electron microprobe analyses from amphibole (wt. \% and apfu based on $23 \mathrm{O}$ )

\begin{tabular}{|c|c|c|c|c|c|c|c|c|c|c|c|}
\hline Sample & 1 & 2 & 3 & 4 & 5 & 6 & 7 & 8 & 9 & 10 & 11 \\
\hline $\mathrm{SiO}_{2}$ & 43.81 & 44.40 & 41.89 & 42.68 & 53.40 & 54.84 & 48.99 & 46.38 & 49.58 & 51.31 & 54.16 \\
\hline $\mathrm{TiO}_{2}$ & 1.11 & 1.47 & 0.37 & 0.32 & 0.11 & 0.10 & 0.86 & 0.25 & 0.24 & 0.74 & 0.83 \\
\hline $\mathrm{Al}_{2} \mathrm{O}_{3}$ & 9.69 & 9.28 & 13.98 & 13.72 & 2.15 & 1.38 & 6.15 & 8.85 & 5.13 & 4.10 & 2.05 \\
\hline $\mathrm{Cr}_{2} \mathrm{O}_{3}$ & n.d. & n.d. & n.d. & n.d. & n.d. & n.d. & n.d. & n.d. & n.d. & 0.22 & 0.28 \\
\hline $\mathrm{FeO}$ & 18.43 & 18.77 & 17.50 & 17.41 & 12.30 & 10.97 & 14.15 & 18.27 & 17.41 & 14.59 & 10.66 \\
\hline $\mathrm{MnO}$ & 0.36 & 0.34 & 0.32 & 0.35 & 0.21 & 0.24 & 0.26 & 0.27 & 0.36 & 0.32 & 0.25 \\
\hline $\mathrm{MgO}$ & 9.54 & 9.44 & 8.71 & 8.91 & 15.70 & 16.98 & 13.19 & 9.79 & 11.64 & 13.70 & 16.56 \\
\hline $\mathrm{CaO}$ & 11.99 & 11.77 & 11.30 & 11.82 & 12.51 & 12.45 & 11.92 & 11.90 & 12.30 & 12.32 & 12.78 \\
\hline $\mathrm{Na}_{2} \mathrm{O}$ & 0.89 & 1.04 & 1.25 & 1.17 & 0.15 & 0.12 & 0.51 & 0.83 & 0.56 & 0.41 & 0.18 \\
\hline $\mathrm{K}_{2} \mathrm{O}$ & 0.76 & 0.74 & 0.24 & 0.28 & n.d. & n.d. & 0.25 & 0.20 & 0.17 & 0.08 & 0.03 \\
\hline Total & 96.57 & 97.24 & 95.56 & 96.67 & 96.53 & 97.08 & 96.27 & 96.57 & 97.39 & 97.78 & 97.77 \\
\hline $\mathrm{Si}$ & 6.693 & 6.737 & 6.406 & 6.449 & 7.765 & 7.862 & 7.256 & 6.991 & 7.374 & 7.480 & 7.726 \\
\hline $\mathrm{Al}^{\mathrm{IV}}$ & 1.307 & 1.263 & 1.594 & 1.551 & 0.235 & 0.138 & 0.744 & 1.009 & 0.626 & 0.520 & 0.274 \\
\hline $\mathrm{Al}^{\mathrm{VI}}$ & 0.438 & 0.397 & 0.925 & 0.892 & 0.133 & 0.096 & 0.329 & 0.564 & 0.273 & 0.184 & 0.071 \\
\hline $\mathrm{Ti}$ & 0.127 & 0.168 & 0.043 & 0.036 & 0.012 & 0.011 & 0.095 & 0.029 & 0.027 & 0.081 & 0.090 \\
\hline $\mathrm{Cr}$ & 0.000 & 0.000 & 0.000 & 0.000 & 0.000 & 0.000 & 0.000 & 0.000 & 0.000 & 0.026 & 0.031 \\
\hline $\mathrm{Mn}$ & 0.046 & 0.043 & 0.041 & 0.045 & 0.026 & 0.029 & 0.033 & 0.035 & 0.046 & 0.039 & 0.030 \\
\hline $\mathrm{Mg}$ & 2.172 & 2.137 & 1.986 & 2.008 & 3.402 & 3.630 & 2.914 & 2.20 & 2.581 & 2.977 & 3.521 \\
\hline $\mathrm{Fe}^{2+}$ & 2.216 & 2.255 & 2.006 & 2.018 & 1.426 & 1.233 & 1.629 & 2.172 & 2.073 & 1.694 & 1.256 \\
\hline $\mathrm{Fe}^{2+}$ & 0.139 & 0.126 & 0.233 & 0.182 & 0.069 & 0.081 & 0.124 & 0.131 & 0.092 & 0.085 & 0.015 \\
\hline $\mathrm{Ca}$ & 1.963 & 1.914 & 1.852 & 1.914 & 1.949 & 1.912 & 1.891 & 1.922 & 1.960 & 1.924 & 1.953 \\
\hline $\mathrm{Na}$ & 0.365 & 0.346 & 0.454 & 0.438 & 0.060 & 0.026 & 0.162 & 0.297 & 0.215 & 0.125 & 0.018 \\
\hline $\mathrm{K}$ & 0.147 & 0.143 & 0.046 & 0.053 & 0.000 & 0.000 & 0.047 & 0.038 & 0.033 & 0.014 & 0.005 \\
\hline $\mathrm{XMg}(\mathrm{mol})$ & 0.480 & 0.473 & 0.470 & 0.477 & 0.695 & 0.734 & 0.624 & 0.489 & 0.544 & 0.626 & 0.735 \\
\hline
\end{tabular}

Nr. 1-2, J/14b/93; biotite-amphibole diorites (Tetčice suite)

Nr. 3-7; diorites, plutonic complex (Ophiolite Belt): 3-4 rim; 5-6 core; 7 transition core-rim

Nr.8-11 metabasalts, volcanic complex (Ophiolite Belt): 8-9 rim; 10-11 core

n.d. - nit determined

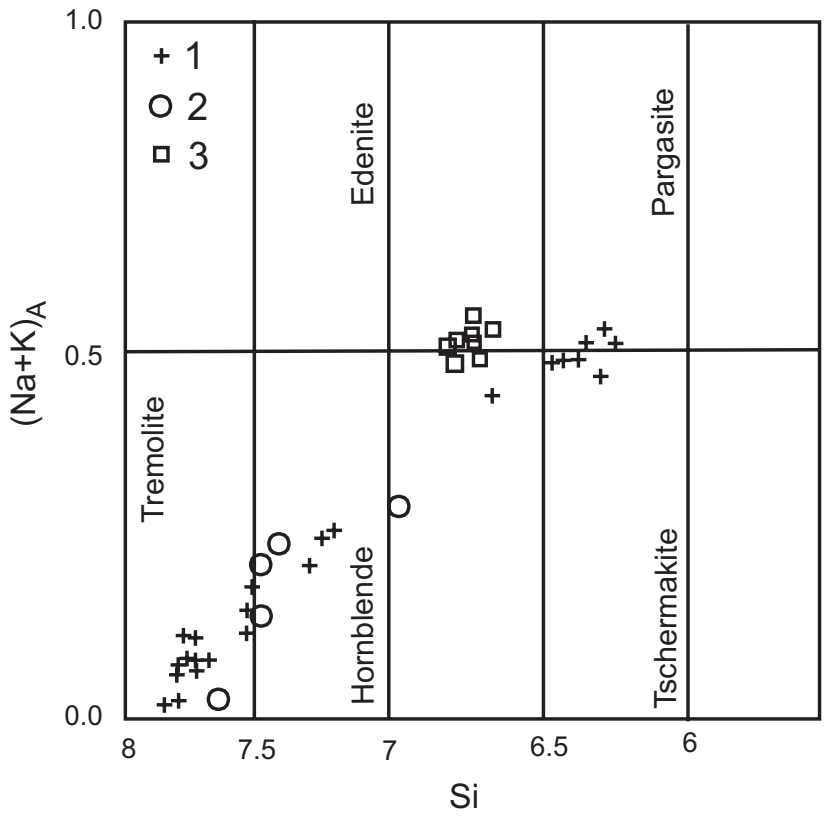

As in the plutonic sequence, the original mineralogy was overprinted by a metamorphic assemblage. The mafic metavolcanics consist mainly of amphibole and plagioclase $\left(\mathrm{An}_{5-15}\right)$. Other important phases are chlorite, epidote, zoisite, carbonate and white mica. Increasing content of secondary white mica is accompanied by an increase in alkalis in the whole-rock geochemical analyses. Thus, the geochemical classification of the volcanic products based on the TAS diagram (Fig. 4) has to be considered with caution. This is particularly important for the analyses plotting in, or close to, the field of the

Fig. 3 Classification of the Ca-rich amphiboles according to Deer et al. (1992) in the binary plot $\mathrm{Si}$ vs. $\mathrm{Na}+\mathrm{K}$ in the A position (atoms per formula unit).

1 - amphiboles from diorites, magmatic complex, Metabasite Zone

2 - amphiboles from basalts, volcanic complex, Metabasite Zone

3 - amphiboles from diorites, Tetčice suite, Western Granitoid Complex 
Tab. 3a Whole-rock major- and trace-element analyses from the Western Granitoid Complex and the Ophiolite Belt (wt. \% and ppm)

\begin{tabular}{|c|c|c|c|c|c|c|c|c|c|c|c|c|c|c|c|}
\hline Sample & 1 & 2 & 3 & 4 & 5 & 6 & 7 & 8 & 9 & 10 & 11 & 12 & 13 & 14 & 15 \\
\hline & $\mathrm{J} / 8$ & $\mathrm{~J} / 9$ & $\mathrm{~J} / 10$ & $\mathrm{~J} / 22$ & $\mathrm{~J} / 3$ & $\mathrm{~J} / 19$ & $\mathrm{~J} / 4$ & $\mathrm{~J} / 5$ & $\mathrm{~J} / 6$ & $\mathrm{~J} / 1 \mathrm{c}$ & $\mathrm{J} / 14 \mathrm{~b}$ & $\mathrm{~J} / 15$ & $\mathrm{~J} / 16$ & $\mathrm{~J} / 20$ & $\mathrm{~J} / 23$ \\
\hline $\mathrm{SiO}_{2}$ & 71.97 & 73.35 & 69.43 & 70.14 & 71.86 & 71.86 & 72.19 & 73.43 & 72.33 & 51.67 & 51.42 & 64.55 & 74.04 & 73.46 & 74.21 \\
\hline $\mathrm{TiO}_{2}$ & 0.26 & 0.16 & 0.37 & 0.35 & 0.27 & 0.21 & 0.21 & 0.13 & 0.27 & 1.46 & 1.39 & 0.32 & 0.15 & 0.11 & 0.21 \\
\hline $\mathrm{Al}_{2} \mathrm{O}_{3}$ & 14.59 & 14.28 & 15.11 & 15.38 & 14.67 & 15.17 & 14.96 & 15.11 & 15.64 & 18.16 & 18.75 & 18.33 & 13.92 & 13.74 & 13.74 \\
\hline $\mathrm{FeO}$ & 2.05 & 1.46 & 2.83 & 2.54 & 2.04 & 1.55 & 1.81 & 1.24 & 2.09 & 8.80 & 9.04 & 2.80 & 1.25 & 1.41 & 1.57 \\
\hline $\mathrm{MnO}$ & 0.01 & 0.07 & 0.43 & 0.09 & 0.10 & 0.04 & 0.04 & 0.00 & 0.00 & 0.13 & 0.15 & 0.09 & 0.00 & 0.00 & 0.00 \\
\hline $\mathrm{MgO}$ & 0.74 & 0.46 & 1.25 & 0.97 & 0.54 & 0.38 & 0.67 & 0.53 & 0.40 & 4.62 & 4.56 & 0.95 & 0.36 & 0.23 & 0.51 \\
\hline $\mathrm{CaO}$ & 2.22 & 1.95 & 2.73 & 2.69 & 2.05 & 2.29 & 1.41 & 1.84 & 1.56 & 7.79 & 8.08 & 4.25 & 1.24 & 1.35 & 0.62 \\
\hline $\mathrm{Na}_{2} \mathrm{O}$ & 3.25 & 3.24 & 3.29 & 3.64 & 3.64 & 3.87 & 4.34 & 4.23 & 4.66 & 3.71 & 3.65 & 4.51 & 3.13 & 3.25 & 3.39 \\
\hline $\mathrm{K}_{2} \mathrm{O}$ & 3.83 & 3.82 & 3.36 & 2.88 & 3.46 & 3.15 & 2.55 & 3.37 & 2.82 & 2.32 & 1.74 & 2.18 & 4.61 & 4.68 & 5.13 \\
\hline $\mathrm{P}_{2} \mathrm{O}_{5}$ & 0.05 & 0.00 & 0.09 & 0.11 & 0.09 & 0.03 & 0.05 & 0.00 & 0.02 & 0.64 & 0.44 & 0.10 & 0.00 & 0.07 & 0.07 \\
\hline LOI & 0.90 & 0.75 & 1.15 & 1.45 & 1.05 & 0.80 & 1.10 & 0.75 & 0.40 & 1.40 & 1.40 & 1.00 & 0.95 & 0.85 & 0.60 \\
\hline Sum & 99.87 & 99.53 & 99.65 & 100.23 & 99.76 & 99.35 & 99.32 & 100.62 & 100.20 & 100.71 & 100.62 & 99.06 & 99.66 & 99.47 & 100.08 \\
\hline $\mathrm{Nb}$ & 10 & 11 & 11 & 12 & 15 & 11 & 9 & 7 & 15 & 22 & 23 & 10 & 17 & 7 & 15 \\
\hline $\mathrm{Zr}$ & 92 & 71 & 121 & 120 & 92 & 125 & 147 & 80 & 324 & 220 & 182 & 227 & 155 & 109 & 166 \\
\hline $\mathrm{Y}$ & 19 & 10 & 22 & 17 & 25 & 14 & 16 & 10 & 17 & 34 & 31 & 10 & 18 & 13 & 17 \\
\hline $\mathrm{Sr}$ & 211 & 169 & 268 & 303 & 266 & 356 & 384 & 427 & 197 & 793 & 823 & 684 & 270 & 307 & 196 \\
\hline $\mathrm{Rb}$ & 150 & 163 & 134 & 114 & 120 & 94 & 87 & 104 & 79 & 75 & 53 & 57 & 123 & 100 & 133 \\
\hline $\mathrm{Pb}$ & 19 & 18 & 22 & 18 & 16 & 20 & 16 & 24 & 14 & 18 & 17 & 16 & 15 & 14 & 17 \\
\hline $\mathrm{Ga}$ & 16 & 15 & 17 & 17 & 18 & 18 & 15 & 16 & 18 & 22 & 23 & 20 & 17 & 15 & 15 \\
\hline $\mathrm{Zn}$ & 48 & 31 & 51 & 48 & 42 & 42 & 20 & 45 & 38 & 99 & 91 & 42 & 17 & 19 & 24 \\
\hline $\mathrm{Cu}$ & 9 & 4 & 7 & 7 & 9 & 6 & 7 & 12 & 4 & 24 & 17 & 13 & 19 & 10 & 10 \\
\hline $\mathrm{Ni}$ & 11 & 7 & 9 & 9 & 8 & 9 & 8 & 9 & 6 & 23 & 18 & 9 & 6 & 7 & 9 \\
\hline Co & 11 & 6 & 6 & 4 & 4 & 2 & 6 & 8 & 8 & 22 & 22 & 6 & 8 & 3 & 4 \\
\hline $\mathrm{Ba}$ & 462 & 322 & 525 & 473 & 444 & 622 & 849 & 1284 & 1554 & 1364 & 648 & 767 & 1185 & 779 & 796 \\
\hline $\mathrm{Sc}$ & 4 & 2 & 5 & 4 & 4 & 1 & 2 & 0 & 4 & 27 & 24 & 3 & 2 & 1 & 0 \\
\hline $\mathrm{Cr}$ & 8 & 7 & 8 & 3 & 4 & 0 & 1 & 4 & 7 & 137 & 96 & 2 & 3 & 0 & 0 \\
\hline $\mathrm{V}$ & 20 & 11 & 31 & 20 & 12 & 6 & 15 & 8 & 3 & 192 & 156 & 23 & 5 & 3 & 7 \\
\hline $\mathrm{K} / \mathrm{Rb}$ & 211 & 195 & 208 & 210 & 239 & 278 & 243 & 269 & 296 & 256 & 272 & 317 & 311 & 388 & 320 \\
\hline $\mathrm{K} / \mathrm{Ba}$ & 67 & 98 & 53 & 50 & 64 & 42 & 24.9 & 18 & 17.2 & 14 & 22 & 24 & 32 & 49.9 & 53 \\
\hline $\mathrm{mg} \#$ & 27 & 24 & 31 & 28 & 21 & 28 & 27 & 30 & 16 & 34 & 34 & 25 & 22 & 14 & 25 \\
\hline
\end{tabular}

Nr. 1-6 Rena suite: 1-4 amphibole-biotite granodiorites; 5-6 biotite granodiorites-granites

Nr. 7-12 Tetčice suite: 7-9 biotite granodiorites; 10-11 biotite-amphibole diorites; 12 biotite tonalite

Nr. 13-15 red granites

trachybasalts (S1), basaltic trachyandesites (S2) and trachytes (T). Despite of possibly affected alkalis, the TAS diagram indicates a bimodal distribution. The basaltic rocks cluster in one area, but can be separated into two groups based on their trace-element contents (Tab. 3). In the first group, the NMORB-normalized (Pearce and

Fig. 4 Total alkalis-silica (TAS) diagram (Le Maitre 1989). 1 - basalts with MORB character, 2 - enriched basalts, 3 - transitional basalts, 4 - felsic volcanic rocks.

The basalts with MORB character plot in the field of basalts (B), the enriched basalts in the field of basaltic andesites (O1) and basaltic trachyandesites (S2), The felsic volcanic rocks fall into the field of rhyolites (R) and trachytes (T).

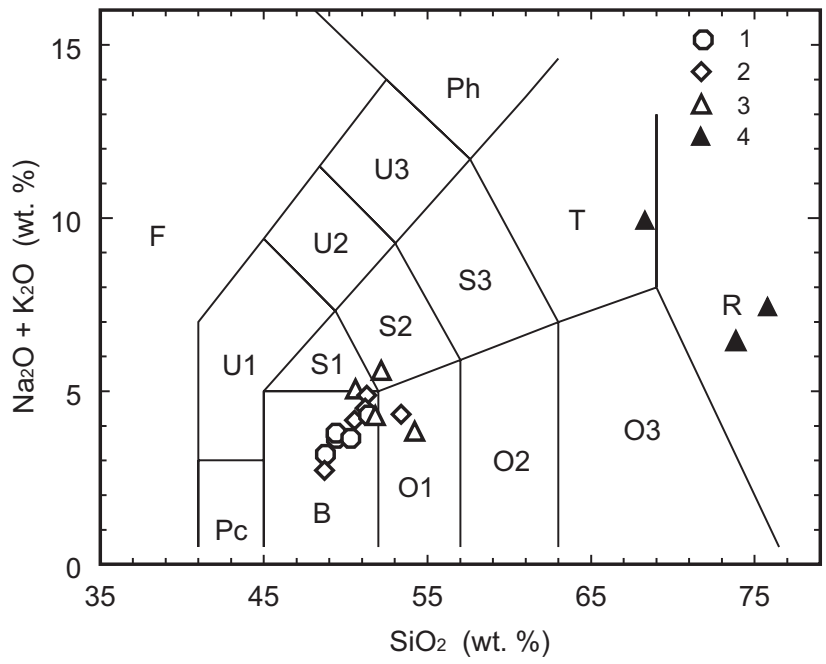


Tab. 3a Continued

\begin{tabular}{|c|c|c|c|c|c|c|c|c|c|c|c|c|c|c|}
\hline \multirow[t]{2}{*}{ Sample } & 16 & 17 & 18 & 19 & 20 & 21 & 22 & 23 & 24 & 25 & 26 & 27 & 28 & 29 \\
\hline & $\mathrm{J} / 29$ & $\mathrm{~J} / 21 \mathrm{~b}$ & $\mathrm{~J} / 21 \mathrm{c}$ & $\mathrm{J} \operatorname{Re}$ & J Iv & $\mathrm{J} / 7$ & $\mathrm{~J} / 11$ & $\mathrm{~J} / 24$ & $\mathrm{~J} / 70$ & $\mathrm{~J} / 126$ & $\mathrm{~J} / 79$ & $\mathrm{~J} / 31$ & $\mathrm{~J} / 32$ & $\mathrm{~J} / 33$ \\
\hline $\mathrm{SiO}_{2}$ & 74.11 & 75.79 & 75.86 & 74.92 & 75.46 & 72.95 & 74.47 & 72.83 & 52.73 & 51.78 & 49.66 & 47.25 & 50.81 & 47.43 \\
\hline $\mathrm{TiO}_{2}$ & 0.20 & 0.03 & 0.04 & 0.04 & 0.04 & 0.27 & 0.14 & 0.22 & 0.72 & 0.84 & 0.44 & 1.15 & 2.46 & 1.72 \\
\hline $\mathrm{Al}_{2} \mathrm{O}_{3}$ & 13.62 & 13.64 & 13.60 & 13.48 & 13.27 & 15.40 & 14.27 & 15.07 & 19.15 & 19.57 & 7.98 & 16.37 & 14.79 & 14.89 \\
\hline $\mathrm{FeO}$ & 1.68 & 0.9 & 0.71 & 0.79 & 0.84 & 2.02 & 1.38 & 1.74 & 8.12 & 8.07 & 8.07 & 9.21 & 12.32 & 11.75 \\
\hline $\mathrm{MnO}$ & 0.00 & 0.1 & 0.09 & 0.04 & 0.9 & 0.05 & 0.09 & 0.00 & 0.14 & 0.16 & 0.16 & 0.16 & 0.23 & 0.19 \\
\hline $\mathrm{MgO}$ & 0.44 & 0.03 & 0.03 & 0.03 & 0.02 & 1.13 & 0.68 & 0.88 & 5.13 & 5.44 & 20.76 & 9.50 & 4.61 & 6.57 \\
\hline $\mathrm{CaO}$ & 0.36 & 0.96 & 1.02 & 1.16 & 0.61 & 0.96 & 0.95 & 1.53 & 8.12 & 9.77 & 8.83 & 10.02 & 6.00 & 11.92 \\
\hline $\mathrm{Na}_{2} \mathrm{O}$ & 3.80 & 3.85 & 3.85 & 3.93 & 4.18 & 4.52 & 4.51 & 4.44 & 3.46 & 3.44 & 1.00 & 2.23 & 4.73 & 2.50 \\
\hline $\mathrm{K}_{2} \mathrm{O}$ & 4.89 & 4.21 & 4.29 & 4.15 & 4.11 & 1.26 & 1.28 & 0.83 & 0.69 & 0.44 & 0.14 & 0.85 & 0.72 & 0.14 \\
\hline $\mathrm{P}_{2} \mathrm{O}_{5}$ & 0.04 & 0.02 & 0.01 & 0.01 & 0.01 & 0.06 & 0.07 & 0.00 & 0.19 & 0.16 & 0.00 & 0.16 & 0.75 & 0.25 \\
\hline LOI & 1.10 & 0.30 & 0.30 & 0.70 & 0.50 & 1.75 & 1.50 & 1.70 & 2.40 & 1.40 & 2.95 & 3.15 & 2.30 & 2.70 \\
\hline Sum & 100.21 & 99.71 & 99.8 & 99.25 & 99.13 & 100.34 & 99.33 & 99.24 & 100.86 & 101.07 & 100.00 & 100.02 & 99.72 & 100.04 \\
\hline $\mathrm{Nb}$ & 9 & 51 & 45.5 & 19 & 23 & 5 & 7 & 6 & 3 & 4 & 2 & 3 & 12 & 5 \\
\hline $\mathrm{Zr}$ & 147 & 79 & 74 & 76 & 72 & 80 & 100 & 91 & 7 & 24 & 10 & 76 & 285 & 120 \\
\hline $\mathrm{Y}$ & 16 & 56 & 47 & 23 & 14 & 9 & 10 & 9 & 8 & 11 & 7 & 23 & 72 & 35 \\
\hline $\mathrm{Sr}$ & 384 & 22 & 21 & 30 & 16 & 264 & 300 & 295 & 438 & 558 & 69 & 198 & 152 & 286 \\
\hline $\mathrm{Rb}$ & 87 & 174 & 156 & 174 & 311 & 25 & 20 & 15 & 19 & 13 & 3 & 20 & 17 & 3 \\
\hline $\mathrm{Pb}$ & 16 & 11 & 6 & 8 & 24 & 14 & 9 & 10 & 10 & 11 & 9 & 4 & 11 & 7 \\
\hline $\mathrm{Ga}$ & 15 & 24 & 21 & 20 & 19 & 15 & 14 & 15 & 18 & 18 & 9 & 17 & 26 & 22 \\
\hline $\mathrm{Zn}$ & 20 & 9 & 7 & 12 & 12 & 62 & 45 & 61 & 89 & 95 & 60 & 81 & 151 & 97 \\
\hline $\mathrm{Cu}$ & 7 & 1 & b.d.l. & 4 & 13 & 51 & 7 & 18 & 80 & 131 & 43 & 70 & 27 & 120 \\
\hline $\mathrm{Ni}$ & 8 & b.d.l. & b.d.l. & b.d.l. & b.d.l. & 9 & 6 & 6 & 43 & 47 & 597 & 172 & 50 & 71 \\
\hline $\mathrm{Co}$ & 6 & 1 & b.d.1. & b.d.l. & 1 & 7 & 2 & 8 & 35 & 36 & 78 & 43 & 24 & 37 \\
\hline $\mathrm{Ba}$ & 849 & 18 & 14 & 17 & 46 & 488 & 517 & 329 & 106 & 95 & 37 & 213 & 192 & 41 \\
\hline $\mathrm{Sc}$ & 2 & 2 & 2 & 2 & 1 & 2 & 2 & 3 & 32 & 33 & 27 & 30 & 33 & 39 \\
\hline $\mathrm{Cr}$ & 1 & b.d.1 & b.d.l. & b.d.l. & b.d.1. & 6 & 0 & 3 & 157 & 163 & 2111 & 320 & 98 & 126 \\
\hline $\mathrm{V}$ & 15 & 5 & b.d.1. & b.d.1. & b.d.1. & 35 & 6 & 22 & 364 & 311 & 188 & 213 & 252 & 292 \\
\hline $\mathrm{K} / \mathrm{Rb}$ & 466 & 201 & 228 & 198 & 110 & 418 & 531 & 459 & 301 & 281 & 387 & 352 & 351 & 387 \\
\hline $\mathrm{K} / \mathrm{Ba}$ & 48 & 1941 & 2544 & 2026 & 742 & 21 & 21 & 21 & 54 & 38 & 31 & 31 & 31 & 28 \\
\hline $\mathrm{mg \#}$ & 21 & 5 & 7 & 6 & 5 & 36 & 33 & 34 & 39 & 40 & 72 & 51 & 27 & 36 \\
\hline
\end{tabular}

Nr. 16 red granites

Nr. 17-20 Hlína suite: garnet-bearing granites

Nr. 21-26 magmatic complex, Ophiolite Belt: 21-23 trondhjemites; 24-25 diorites; 26 gabbro

Nr. 27-29 volcanic complex, Ophiolite Belt: mafic volcanics

Cann 1973) concentrations (Fig. 5a) for $\mathrm{Sr}, \mathrm{Nb}, \mathrm{P}, \mathrm{Zr}$, $\mathrm{Ti}, \mathrm{Sc}$ and $\mathrm{Cr}$, resemble closely typical MOR basalts (Pearce and Cann 1973). The enrichment in K, Rb, and $\mathrm{Ba}$ is probably connected with the alteration processes. In contrast, the second group of mafic volcanic rocks is enriched in elements such as $\mathrm{P}, \mathrm{Ti}, \mathrm{Nb}, \mathrm{Y}, \mathrm{Zr}$, combined with low concentrations of $\mathrm{Cr}$ and Sc. As evidenced by the NMORB-normalized multi-element plot (Fig. 5b), they show a strong within-plate affinity. Both groups are connected by basalts, which are only moderately enriched in HFSE and depleted in $\mathrm{Cr}$ and Sc. The basalts with a MORB-like signature prevail in the southern part of the Metabasite Zone, whereas the enriched basalts are more widespread in the North.
The acid volcanic rocks form concordant layers, or discordant dykes, in the metabasalts. Their thickness ranges from few decimetres to several metres, but does not exceed $100 \mathrm{~m}$. They are usually very fine grained and are, therefore, microscopically undistinguishable from each other.

Two acidic layers, each from geochemically contrasting basalt group, were studied in the detail for this reason only. The first one, a rhyolite layer within the basalts with a MORB-like signature shows elevated $\mathrm{Nb}, \mathrm{Zr}$, and Y contents (Tab. 3), thus resembling geochemically a "Hypothetical Ocean Ridge Granite" (HORG) according to Pearce et al. (1984). The second represents a trachyte layer within basalts with the intraplate signature. It re- 
Tab. 3a Continued

\begin{tabular}{|c|c|c|c|c|c|c|c|c|c|c|c|c|c|c|}
\hline \multirow[t]{2}{*}{ Sample } & 30 & 31 & 32 & 33 & 34 & 35 & 36 & 37 & 38 & 39 & 40 & 41 & 42 & 43 \\
\hline & $\mathrm{J} / 34$ & $\mathrm{~J} / 35$ & $\mathrm{~J} / 38$ & $\mathrm{~J} / 40$ & $\mathrm{~J} / 41$ & $\mathrm{~J} / 42$ & $\mathrm{~J} / 44$ & $\mathrm{~J} / 45$ & $\mathrm{~J} / 46$ & $\mathrm{~J} / 47$ & $\mathrm{~J} / 49$ & $\mathrm{~J} / 43$ & $\mathrm{~J} / 36$ & $\mathrm{~J} / 27$ \\
\hline $\mathrm{SiO}_{2}$ & 50.01 & 50.40 & 52.62 & 46.92 & 49.83 & 49.40 & 52.39 & 48.46 & 50.76 & 49.21 & 50.76 & 78.60 & 67.84 & 74.36 \\
\hline $\mathrm{TiO}_{2}$ & 2.64 & 1.66 & 1.92 & 1.44 & 1.50 & 1.84 & 2.32 & 1.51 & 1.63 & 1.49 & 1.93 & 0.16 & 0.37 & 0.00 \\
\hline $\mathrm{Al}_{2} \mathrm{O}_{3}$ & 13.17 & 14.85 & 14.99 & 16.54 & 15.45 & 14.72 & 13.98 & 16.41 & 15.06 & 15.12 & 14.80 & 11.10 & 17.26 & 13.97 \\
\hline $\mathrm{FeO}$ & 14.14 & 10.78 & 10.74 & 11.74 & 10.06 & 11.49 & 12.45 & 10.17 & 10.86 & 10.64 & 9.59 & 1.27 & 2.11 & 0.60 \\
\hline $\mathrm{MnO}$ & 0.20 & 0.27 & 0.25 & 0.17 & 0.21 & 0.21 & 0.21 & 0.20 & 0.23 & 0.21 & 0.22 & 0.00 & 0.00 & 0.00 \\
\hline $\mathrm{MgO}$ & 5.48 & 7.23 & 5.12 & 9.47 & 7.45 & 7.00 & 4.94 & 7.37 & 7.26 & 7.60 & 5.69 & 0.09 & 0.97 & 0.09 \\
\hline $\mathrm{CaO}$ & 7.80 & 8.04 & 7.02 & 5.01 & 8.91 & 8.79 & 7.18 & 10.02 & 8.56 & 9.77 & 10.15 & 1.02 & 1.01 & 1.23 \\
\hline $\mathrm{Na}_{2} \mathrm{O}$ & 3.82 & 4.16 & 3.46 & 3.14 & 4.15 & 3.78 & 3.81 & 2.43 & 3.78 & 3.14 & 3.69 & 3.77 & 5.60 & 3.12 \\
\hline $\mathrm{K}_{2} \mathrm{O}$ & 1.18 & 0.64 & 0.27 & 0.31 & 0.24 & 0.29 & 0.44 & 1.15 & 0.48 & 0.42 & 0.52 & 2.88 & 3.73 & 4.50 \\
\hline $\mathrm{P}_{2} \mathrm{O}_{5}$ & 0.38 & 0.25 & 0.66 & 0.16 & 0.26 & 0.21 & 0.39 & 0.24 & 0.16 & 0.19 & 0.64 & 0.00 & 0.20 & 0.00 \\
\hline LOI & 1.45 & 2.25 & 2.20 & 5.90 & 2.55 & 2.20 & 2.15 & 2.70 & 1.80 & 1.45 & 1.20 & 0.65 & 1.20 & 1.85 \\
\hline Sum & 100.28 & 100.53 & 99.27 & 100.8 & 99.89 & 99.93 & 100.25 & 100.66 & 100.61 & 99.24 & 99.19 & 99.54 & 100.29 & 99.72 \\
\hline $\mathrm{Nb}$ & 8 & 7 & 11 & 3 & 9 & 4 & 12 & 4 & 4 & 4 & 11 & 21 & 12 & 25 \\
\hline $\mathrm{Zr}$ & 222 & 131 & 245 & 81 & 170 & 116 & 237 & 102 & 91 & 85 & 186 & 292 & 197 & 74 \\
\hline $\mathrm{Y}$ & 54 & 32 & 64 & 24 & 39 & 34 & 49 & 31 & 28 & 27 & 50 & 54 & 14 & 19 \\
\hline $\mathrm{Sr}$ & 151 & 222 & 222 & 90 & 222 & 175 & 232 & 198 & 232 & 234 & 208 & 88 & 67 & 78 \\
\hline $\mathrm{Rb}$ & 41 & 18 & 6 & 8 & 7 & 6 & 13 & 34 & 9 & 13 & 14 & 44 & 69 & 195 \\
\hline $\mathrm{Pb}$ & 9 & 17 & 33 & 3 & 13 & 6 & 16 & 11 & 8 & 15 & 25 & 9 & 11 & 14 \\
\hline $\mathrm{Ga}$ & 23 & 18 & 22 & 18 & 18 & 19 & 22 & 17 & 19 & 18 & 20 & 14 & 16 & 16 \\
\hline $\mathrm{Zn}$ & 131 & 121 & 385 & 18 & 115 & 115 & 107 & 112 & 109 & 88 & 176 & 12 & 34 & 26 \\
\hline $\mathrm{Cu}$ & 40 & 78 & 34 & 48 & 58 & 120 & 80 & 88 & 84 & 42 & 45 & 5 & 6 & 7 \\
\hline $\mathrm{Ni}$ & 39 & 94 & 56 & 128 & 115 & 58 & 47 & 124 & 79 & 98 & 59 & 10 & 9 & 6 \\
\hline Co & 18 & 40 & 21 & 59 & 43 & 39 & 34 & 34 & 37 & 41 & 32 & 6 & 8 & 4 \\
\hline $\mathrm{Ba}$ & 187 & 205 & 121 & 119 & 63 & 121 & 285 & 200 & 127 & 101 & 127 & 393 & 1153 & 214 \\
\hline $\mathrm{Sc}$ & 6 & 34 & 30 & 30 & 30 & 39 & 40 & 35 & 39 & 33 & 32 & 5 & 0 & 1 \\
\hline $\mathrm{Cr}$ & 17 & 229 & 105 & 289 & 204 & 159 & 77 & 226 & 197 & 192 & 126 & 19 & 28 & 1 \\
\hline V & 392 & 258 & 169 & 287 & 241 & 308 & 430 & 259 & 301 & 304 & 243 & 8 & 301 & 1 \\
\hline $\mathrm{K} / \mathrm{Rb}$ & 238 & 295 & 373 & 321 & 284 & 401 & 281 & 281 & 442 & 298 & 308 & 543 & 462 & 191 \\
\hline $\mathrm{K} / \mathrm{Ba}$ & 59 & 26 & 19 & 22 & 32 & 20 & 13 & 47 & 31 & 35 & 34 & 60 & 26 & 174 \\
\hline $\mathrm{mg \#}$ & 28 & 40 & 25 & 45 & 42 & 38 & 28 & 42 & 40 & 42 & 37 & 7 & 31 & 13 \\
\hline
\end{tabular}

Nr. 30-43 volcanic complex, Ophiolite Belt: 30-40 mafic volcanics, 41-43 rhyolites

Tab 3b Concentration of Rare Earth elements, Hlína suite, garnet-bearing granites

\begin{tabular}{lccccccccccccccccc}
\hline Sample & $\mathrm{La}$ & $\mathrm{Ce}$ & $\mathrm{Pr}$ & $\mathrm{Nd}$ & $\mathrm{Sm}$ & $\mathrm{Eu}$ & $\mathrm{Gd}$ & $\mathrm{Tb}$ & $\mathrm{Dy}$ & $\mathrm{Ho}$ & $\mathrm{Er}$ & $\mathrm{Tm}$ & $\mathrm{Yb}$ & $\mathrm{Lu}$ & $\mathrm{U}$ & $\mathrm{Th}$ \\
\hline $\mathrm{J} / 21 \mathrm{~b}$ & 2.00 & 5.00 & 0.87 & 4.30 & 2.20 & 0.21 & 3.44 & 0.74 & 6.51 & 1.64 & 6.30 & 1.23 & 9.18 & 1.74 & 12.30 & 13.90 \\
$\mathrm{~J} / 21 \mathrm{c}$ & 3.00 & 6.60 & 1.16 & 5.00 & 2.80 & 0.19 & 3.26 & 0.71 & 5.53 & 1.45 & 5.08 & 1.02 & 7.08 & 1.44 & 17.00 & 12.40 \\
$\mathrm{~J} \mathrm{Re}$ & 3.50 & 6.70 & 1.25 & 5.10 & 2.30 & 0.27 & 2.34 & 0.44 & 2.94 & 0.81 & 2.58 & 0.46 & 4.43 & 0.76 & 7.10 & 13.10 \\
$\mathrm{~J} \mathrm{IV}$ & 1.90 & 5.20 & 0.53 & 2.40 & 1.40 & 0.10 & 2.97 & 0.79 & 6.48 & 1.80 & 6.26 & 1.09 & 10.03 & 1.74 & 16.10 & 21.50 \\
\hline
\end{tabular}

sembles by its lower contents of HFSE and a higher LILE rather volcanic-arc granitoids (VAG).

\subsubsection{Metamorphic evolution}

The Metabasite Zone underwent several stages of metamorphic evolution, which are still under investigation.
Nevertheless, some qualitative observations can be presented here.

As already stressed, the metamorphic overprint in the plutonic and volcanic sequences is pervasive. Magmatic relics are extremely rare, and could be only observed in some samples of diorites. The core of some large plagioclase crystals is still composed of homogenous bytownite 

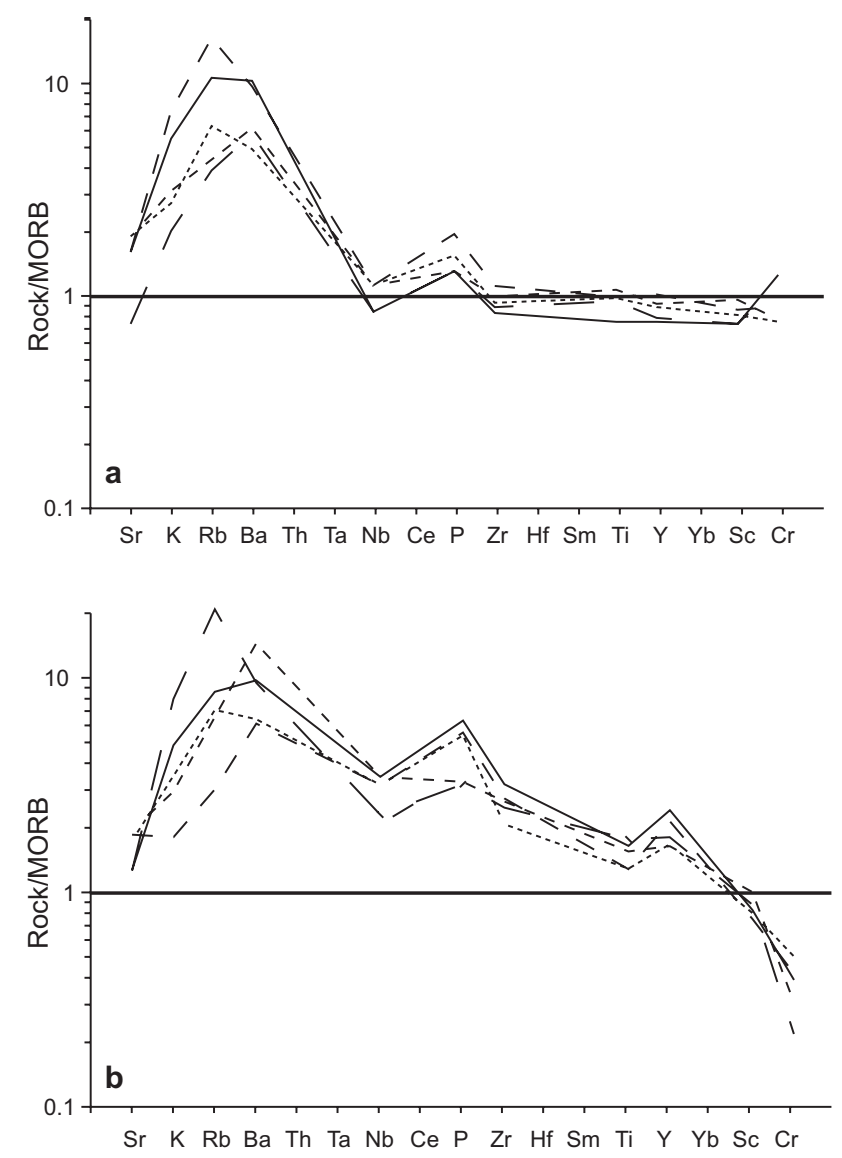

Fig. 5 The MORB-normalized (Pearce and Cann 1973) diagrams. a-MORB-like basalts from the volcanic complex, Metabasite Zone. The content of relatively immobile elements such as $\mathrm{Nb}, \mathrm{P}, \mathrm{Zr}, \mathrm{Ti}, \mathrm{Y}$, $\mathrm{Sc}$ and $\mathrm{Cr}$ correspond well with the MORB characteristics. The enrichment in $\mathrm{K}, \mathrm{Rb}$ and $\mathrm{Ba}$ is connected with later alteration of the rock. b-enriched basalts, volcanic complex, Metabasite Zone.

$\left(\mathrm{An}_{70}\right.$, Tab. 1), reflecting the magmatic stage. Albite/oligoclase rims surrounding the relicts of magmatic plagioclase document the first metamorphic event. The cores of smaller plagioclases from metabasalts were completely replaced by albite/oligoclase. Magmatic pyroxenes were transformed to actinolites in the diorites as well as in the basalts. The mineral assemblage characteristic of the first stage is albite/oligoclase + actinolite.

The second metamorphic phase is documented by an increase in $\mathrm{Al}, \mathrm{Na}, \mathrm{K}$, and decreasing $\mathrm{Si}$ towards the amphibole rims. This process ultimately leads to tschermakite-pargasite rims around actinolite in the diorites, and hornblende rims in the metabasalts (Tab. 2, Fig. 3). Similarly, andesine develops around the albite/oligoclase zones in the metadiorites, whereas oligoclase commonly rims the albite/oligoclase cores in the metabasalts. This medium-grade overprint affected both the plutonic and volcanic complexes of the Metabasite Zone. However its effects can be identified only rarely, where no penetrative deformation occurred, and the magmatic textures are well preserved. Based on the still incomplete data set, the degree of the metamorphic overprinting seems to have been slightly higher within the plutonic complex.

The third metamorphic stage was retrogression. Plagioclases are often partly replaced by white mica, albite, zoisite and epidote. Effects of carbonatization are developed as well, but only locally. Chlorite and epidote replace the amphiboles. In the final stage, only chlorite pseudomorphs after amphibole are seen. The tourmaline veins and pods observed in the strongly altered diorites, along the contact with the Western Granite Complex (Novák and Filip 2002), suggest a circulation of probably granitoid-derived fluids rich in boron, through the rocks of the Metabasite Zone. Circulation of these fluids could have lead to a regional enrichment in $\mathrm{K}$ and probably also $\mathrm{Rb}$ with $\mathrm{Ba}$, i.e. the elements responsible for the common muscovitization developed within the Metabasite Zone.

\subsection{Granitoids}

As already noted, the Metabasic Zone splits the granitoids of the Brno Batholith into two different parts, the eastern and the western complexes. Regarding the Eastern Granitoid Complex we will refer shortly only to available literature data in the following section. The Western Granitoid Complex was recently investigated by the authors and will be described and discussed in more detail.

\subsubsection{Eastern Granitoid Complex}

The database for the Eastern Granitoid Complex is rather variable as far as geochemical and isotopic data concerns. However the unit is petrographically rather homogenous, being built by amphibole- to amphibole-biotite quartz diorites to granodiorites. Some biotite-bearing leucotonalites and granodiorites belong to this sequence as well. The modal mineralogy includes, apart from quartz, plagioclase and K-feldspar, magmatic biotite with, or without, amphibole. Secondary alteration of rock-forming minerals is widespread (Štelcl and Weiss 1986; Hanžl 1994). The geochemistry is characterized by low contents of $\mathrm{K}$ and $\mathrm{Rb}$, but the granodiorites are rich in $\mathrm{MgO}, \mathrm{Na}_{2} \mathrm{O}, \mathrm{CaO}$ and $\mathrm{Sr}$ (Jelínek and Dudek 1993; Hanžl 1994). In addition few low Sr initial ratios of $0.704-0.705$ and high $\varepsilon_{\mathrm{Nd}}$ values of 0 to +3 are available (Finger et al. 2000a). All these data suggest that the rocks can be interpreted as I-type, volcanic-arc derived granitoids (Pearce et al 1984; Chappell and White 1992).

\subsubsection{Western Granitoid Complex}

The original divisions of the Western Granitoid Complex were based mostly on petrographic descriptions. Thus 
Tab. 4 Electron microprobe analyses from white micas (wt. \% and apfu based on 22 O)

\begin{tabular}{|c|c|c|c|c|c|c|c|c|c|c|}
\hline Sample & 1 & 2 & 3 & 4 & 5 & 6 & 7 & 8 & 9 & 10 \\
\hline $\mathrm{SiO}_{2}$ & 51.52 & 46.88 & 46.53 & 46.86 & 45.72 & 45.95 & 46.44 & 46.11 & 48.51 & 48.28 \\
\hline $\mathrm{TiO}_{2}$ & 0.00 & 0.00 & 0.00 & 0.00 & 0.06 & 0.00 & 0.00 & 0.00 & 0.00 & 0.00 \\
\hline $\mathrm{Al}_{2} \mathrm{O}_{3}$ & 30.60 & 37.63 & 29.62 & 29.71 & 30.75 & 30.24 & 29.28 & 29.65 & 31.63 & 30.95 \\
\hline $\mathrm{BaO}$ & 0.00 & 0.00 & 0.00 & 0.13 & 0.00 & 0.00 & 0.61 & 0.43 & 0.20 & 0.23 \\
\hline $\mathrm{FeO}$ & 0.81 & 0.39 & 4.41 & 3.47 & 6.43 & 5.67 & 4.84 & 4.14 & 1.50 & 1.67 \\
\hline $\mathrm{MnO}$ & 0.05 & 0.07 & 0.05 & 0.00 & 0.09 & 0.08 & 0.00 & 0.00 & 0.00 & 0.05 \\
\hline $\mathrm{MgO}$ & 0.51 & 0.18 & 1.65 & 1.38 & 0.04 & 0.41 & 1.61 & 1.72 & 1.57 & 1.73 \\
\hline $\mathrm{CaO}$ & 0.46 & 0.00 & 0.00 & 0.00 & 0.09 & 0.00 & 0.00 & 0.03 & 0.06 & 0.08 \\
\hline $\mathrm{Na}_{2} \mathrm{O}$ & 2.02 & 0.12 & 0.13 & 0.46 & 0.22 & 0.22 & 0.19 & 0.20 & 0.17 & 0.14 \\
\hline $\mathrm{K}_{2} \mathrm{O}$ & 9.60 & 11.09 & 11.11 & 10.75 & 10.87 & 11.00 & 10.81 & 10.83 & 10.27 & 10.41 \\
\hline Total & 95.57 & 96.36 & 93.50 & 92.76 & 94.27 & 93.57 & 93.79 & 93.11 & 93.91 & 93.54 \\
\hline $\mathrm{Si}$ & 6.779 & 6.134 & 6.445 & 6.504 & 6.340 & 6.398 & 6.456 & 6.429 & 6.535 & 6.550 \\
\hline $\mathrm{Al}^{\mathrm{IV}}$ & 1.221 & 1.866 & 1.555 & 1.498 & 1.660 & 1.602 & 1.541 & 1.571 & 1.495 & 1.450 \\
\hline $\mathrm{Al}^{\mathrm{VI}}$ & 3.525 & 3.938 & 3.281 & 3.364 & 3.366 & 3.360 & 3.259 & 3.300 & 3.556 & 3.499 \\
\hline $\mathrm{Ti}$ & 0.000 & 0.000 & 0.000 & 0.000 & 0.006 & 0.000 & 0.000 & 0.000 & 0.000 & 0.000 \\
\hline $\mathrm{Fe}$ & 0.089 & 0.043 & 0.511 & 0.403 & 0.746 & 0.660 & 0.563 & 0.483 & 0.169 & 0.190 \\
\hline $\mathrm{Mn}$ & 0.006 & 0.008 & 0.006 & 0.000 & 0.011 & 0.009 & 0.000 & 0.000 & 0.000 & 0.006 \\
\hline $\mathrm{Mg}$ & 0.100 & 0.035 & 0.341 & 0.286 & 0.008 & 0.085 & 0.333 & 0.357 & 0.316 & 0.350 \\
\hline $\mathrm{Ca}$ & 0.065 & 0.000 & 0.000 & 0.000 & 0.013 & 0.000 & 0.000 & 0.005 & 0.009 & 0.011 \\
\hline $\mathrm{Na}$ & 0.515 & 0.030 & 0.035 & 0.124 & 0.059 & 0.059 & 0.052 & 0.055 & 0.044 & 0.038 \\
\hline K & 1.612 & 1.851 & 1.963 & 1.903 & 1.923 & 1.954 & 1.919 & 1.927 & 1.766 & 1.801 \\
\hline $\mathrm{XMg}(\mathrm{mol})$ & 0.529 & 0.451 & 0.40 & 0.415 & 0.011 & 0.114 & 0.372 & 0.425 & 0.652 & 0.648 \\
\hline $\mathrm{Mu}$ & 0.735 & 0.984 & 0.983 & 0.939 & 0.964 & 0.971 & 0.973 & 0.970 & 0.971 & 0.974 \\
\hline $\mathrm{Pg}$ & 0.235 & 0.016 & 0.017 & 0.061 & 0.030 & 0.029 & 0.027 & 0.028 & 0.024 & 0.020 \\
\hline $\mathrm{Ma}$ & 0.030 & 0.000 & 0.000 & 0.000 & 0.007 & 0.000 & 0.000 & 0.002 & 0.005 & 0.006 \\
\hline
\end{tabular}

Nr. 1-2, J/5/93; fine-grained, grey biotite granodiorites (Tetčice suite)

Nr. 3-4, J/23/93; red granites (Tetčice suite)

Nr. 5-6, J/21/93; garnet-bearing leucogranites (Hlína suite)

Nr. 7-10, J/24/93; trondhjemites, magmatic complex of the Ophiolite Belt

Štelcl and Weiss (1986) mapped 8 granitoid types, while Mittrenga and Rejl (1993) proposed a different subdivision to 7 petrographic types. Recent study nevertheless implies that some types are genetically related, and can be therefore grouped into fewer granitic suites.

Three principal magmatic suites, Rena, Tetčice, and Hlína, have been identified in the Western Granitoid Complex (Fig. 2). The first two, Rena and Tetčice, are widespread on the surface. The rocks of the third, Hlína suite, form only discrete veins or small intrusive bodies cutting both the previous suites.

The Rena suite, named after a hill southeast of Ivančice, forms the southernmost part of the Brno Batholith. The northern Tetčice suite, termed after small village $15 \mathrm{~km} \mathrm{~W}$ of Brno, is separated from the Rena suite by an approximately W-E trending Ivančice Fault (Mittrenga et al. 1976; Leichmann 1996). The Jihlava river valley between villages Ivančice and Moravské Bránice is a remarkable geomorphological manifestation of this tectonic zone. It is also recognizable in the steep gravimetric gradient up to $20 \mathrm{mGal}$ (Skácelová and Weiss 1978). Geologically the Ivančice Fault separates the relatively light granitoids of the Rena suite in the South, from the more dense Tetčice suite rocks in the North. The direct contact between the two suites cannot be observed because of the younger, Tertiary-Quaternary, sedimentary cover in the Jihlava river valley.

Rena suite is represented by two types of intrusive rocks: (1) felsic $\left(\mathrm{SiO}_{2}>69 \%\right)$, coarse-grained amphibole-biotite granodiorites, which grade into (2) biotite granites. The rocks of the suite contain almost no enclaves; some amphibole-cumulate structures (up to $1 \mathrm{~m}$ long layers with elevated coarse-grained amphibole contents) appear rarely. The modal composition (Tab. 5) includes oscillatory-zoned, often altered, euhedral plagioclase (Tab. 1, $\mathrm{An}_{40-6}, 36-55$ vol. \%), anhedral quartz (23-29\%), euhedral to subhedral K-feldspar (10-26\%), pseudohexagonal biotite $(0.5-8 \%)$, euhedral amphibole (up to $7 \%$ ) and secondary chlorite (up to $10 \%$ ). Titanite, zircon, and apatite are the common accessories. The K- 
Tab. 5 Modal compositions of granitoids from the Western Granitoid Complex (vol. \%)

\begin{tabular}{|c|c|c|c|c|c|c|c|c|c|c|}
\hline Sample & Qtz & P1 & Kfs & $\mathrm{Bt}$ & Amp & Grt & Ms & Chl & Opaque & Rest \\
\hline $1 \mathrm{~J} / 22$ & 27 & 46 & 15 & 8 & 3 & - & - & 1 & - & $x$ \\
\hline $2 \mathrm{~J} / 10$ & 29 & 42 & 13 & 8 & 7 & - & - & 1 & $x$ & $x$ \\
\hline $3 \mathrm{~J} / 140$ & 26 & 44 & 11 & 1 & 7 & - & - & 9 & $x$ & $x$ \\
\hline $4 \mathrm{~J} / 130$ & 25 & 55 & 10 & $x$ & - & - & - & 10 & $x$ & $x$ \\
\hline $5 \mathrm{~J} / 139$ & 23 & 50 & 20 & $x$ & - & - & - & 6 & $x$ & $x$ \\
\hline $6 \mathrm{~J} / 19$ & 26 & 36 & 26 & 4 & - & - & - & 6 & - & 2 \\
\hline $7 \mathrm{~J} / 3$ & 28 & 41 & 23 & 5 & - & - & $x$ & 2 & $x$ & $x$ \\
\hline $8 \mathrm{~J} / 23$ & 22 & 25 & 46 & $x$ & - & - & $x$ & 5 & 2 & $x$ \\
\hline $9 \mathrm{~J} / 23 \mathrm{a}$ & 38 & 22 & 35 & $x$ & - & - & $x$ & 3 & $x$ & 2 \\
\hline $10 \mathrm{~J} / 101$ & 39 & 27 & 30 & $x$ & - & - & $x$ & 3 & $x$ & 1 \\
\hline $11 \mathrm{~J} / 102$ & 39 & 15 & 44 & $x$ & - & - & $x$ & 2 & $x$ & $x$ \\
\hline $12 \mathrm{~J} / 29$ & 38 & 28 & 32 & $x$ & - & - & $x$ & 1 & $x$ & $x$ \\
\hline $13 \mathrm{~J} / 29 \mathrm{a}$ & 30 & 28 & 37 & $x$ & - & - & $x$ & 4 & $x$ & $x$ \\
\hline $14 \mathrm{~J} / 12$ & 35 & 25 & 35 & 5 & - & - & 1 & 1 & - & $x$ \\
\hline $15 \mathrm{~J} / 21$ & 26 & 29 & 41 & x & - & 1 & 2 & $\times$ & 1 & $\times$ \\
\hline $16 \mathrm{~J} / 13$ & 29 & 30 & 38 & 1 & - & 1 & 1 & $x$ & $x$ & $x$ \\
\hline
\end{tabular}

$\times$ concentration of mineral is lower than $1 \%$

- mineral was not found in the sample

Nr. 1-5: amphibole-biotite granodiorites (Rena suite)

Nr. 8-13: red granites (Tetčice suite)

Nr. 6-7: fine-grained grey biotite granodiorites (Tetčice suite)

Nr. 14-16: garnet-bearing leucogranites (Hlína suite)

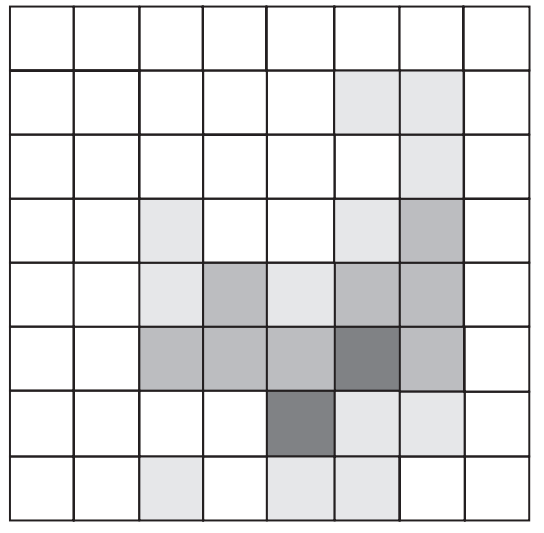

a

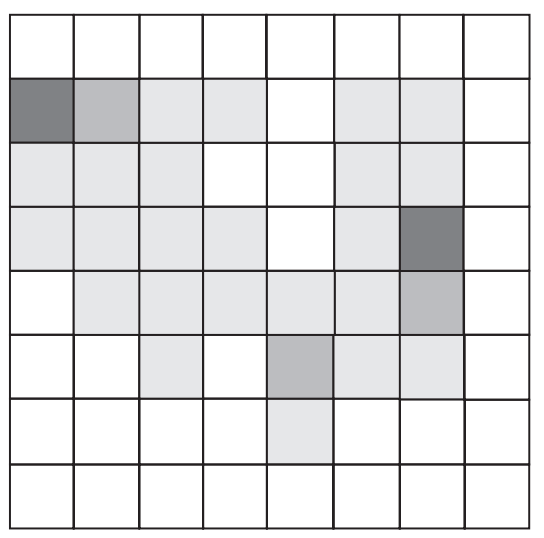

C

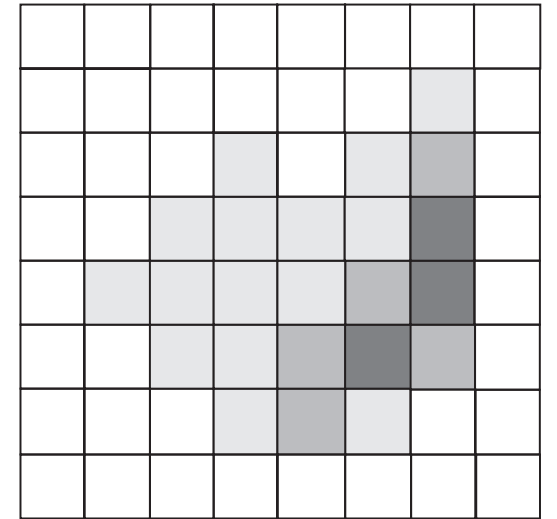

b

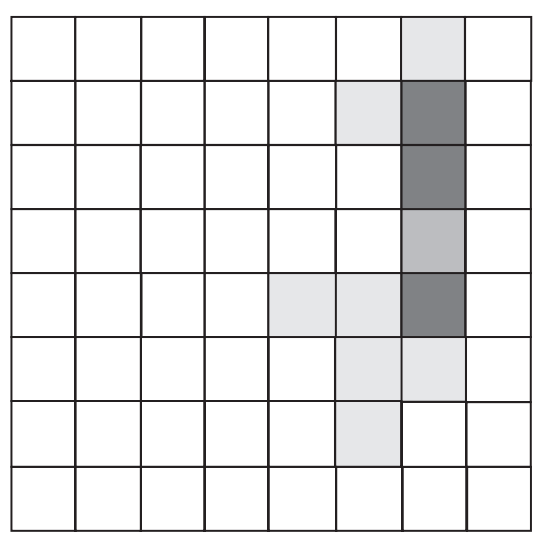

d

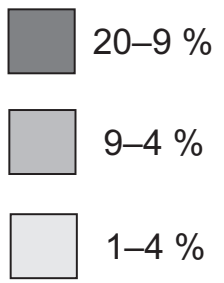

Fig. 6 Zircon typology diagram of Pupin (1980). a - Rena suite, amphibole-biotite granodiorites, $b$ - Rena suite, biotite granites, c - Tetčice suite, biotite granodiorites, d - Hlína suite, garnet-bearing granites. Based on 200 grains examined for each diagram. 
Tab. 6 Electron microprobe analyses from K-feldspar (wt. \%)

\begin{tabular}{crrrrrrrrr}
\hline Sample & $\mathrm{SiO}_{2}$ & $\mathrm{Al}_{2} \mathrm{O}_{3}$ & $\mathrm{Na}_{2} \mathrm{O}$ & $\mathrm{K}_{2} \mathrm{O}$ & $\mathrm{CaO}$ & $\mathrm{BaO}$ & $\mathrm{FeO}$ & $\mathrm{T}$ \\
\hline 1 & 64.6 & 18.3 & 0.46 & 16.5 & 0.00 & 0.27 & 0.00 & 100.16 \\
2 & 64.2 & 18.2 & 0.50 & 16.6 & 0.00 & 0.19 & 0.00 & 99.66 \\
3 & 63.9 & 18.2 & 0.51 & 16.2 & 0.00 & 0.29 & 0.00 & 99.12 \\
4 & 64.4 & 18.2 & 0.43 & 16.5 & 0.00 & 0.25 & 0.00 & 99.78 \\
5 & 63.9 & 18.4 & 0.56 & 16.0 & 0.08 & 0.87 & 0.00 & 99.79 \\
6 & 64.1 & 18.5 & 0.58 & 15.9 & 0.04 & 0.74 & 0.00 & 99.85 \\
7 & 63.8 & 18.4 & 0.42 & 16.4 & 0.09 & 0.88 & 0.00 & 100.01 \\
8 & 63.9 & 18.5 & 0.68 & 15.8 & 0.13 & 0.89 & 0.00 & 99.92 \\
9 & 64.0 & 18.3 & 0.54 & 15.9 & 0.00 & 0.26 & 0.06 & 99.03 \\
10 & 64.4 & 18.3 & 0.78 & 15.8 & 0.00 & 0.27 & 0.07 & 99.62 \\
11 & 64.1 & 18.3 & 0.32 & 16.8 & 0.00 & 0.00 & 0.00 & 99.55 \\
\hline
\end{tabular}

Nr. 1-4, J/10/93: amphibole-biotite granodiorites (Rena Suite)

Nr. 9, 10; J/23/93 red granites, Tetčice suite

Nr. 5-8, J/5/93: fine-grained, grey biotite granodiorite, (Tetčice suite),

Nr.11 rim, 12 core; J/21/93 garnet-bearing leucogranites (Hlína suite)

feldspar (Tab. 6) typically contains small amounts of $\mathrm{Na}_{2} \mathrm{O}(0.43-0.51$ wt. \%) and $\mathrm{BaO}(0.19-0.27$ wt. \%). Biotite appears in two forms: large $(1 \mathrm{~cm})$, often pseudohexagonal crystals differ slightly in their chemistry from the tiny biotite that often overgrows the amphibole grains (Tab. 7). The large grains (points 1,2) differ from the smaller (points 3,4) mainly in their $\mathrm{TiO}_{2}$ and $\mathrm{BaO}$ contents. In the large grains the $\mathrm{TiO}_{2}$ varies from 3.6 to 3.69 wt. $\%$ and $\mathrm{BaO}$ from 0.37 to 0.56 wt. $\%$, whereas the $\mathrm{TiO}_{2}$ in the small grains is slightly lower (3.36-3.41\%), and no $\mathrm{BaO}$ was detected.

The zircons from the amphibole-biotite granodiorites plot in the lower right corner of the Pupin`s (1980) typology diagram (S24, S20, Fig. 6). Zircons from the biotite granite fall in the centre of the right side in the same (P3, S20, P2). Electron microprobe analyses of common titanite are listed in Tab. 8. In the whole rock analysis, the $\mathrm{SiO}_{2}(69.4-73.35$ wt. \%) contents correlate negatively with $\mathrm{MgO}(0.46-1.25 \%), \mathrm{FeO}_{\text {to }}$ (1.46-2.83\%), $\mathrm{CaO}(1.95-2.69 \%)$, and $\mathrm{TiO}_{2}(0.16-0.37 \%)$, as well as positively with $\mathrm{K}_{2} \mathrm{O}(2.88-3.83 \%)$ (Fig. 7, Tab. 3). Only a weak, or no correlation whatever was found between $\mathrm{SiO}_{2}$ and $\mathrm{Al}_{2} \mathrm{O}_{3}(14.28-15.38$ $\%), \mathrm{Na}_{2} \mathrm{O}(3.24-3.64 \%), \mathrm{Ba}(322-622$ ppm), Rb (94-163), and $\mathrm{Sr}$ (169-356). The low contents of HFSE $(\mathrm{Zr}=71-125, \mathrm{Nb}=$ $10-15$, and $Y=10-25 \mathrm{ppm}$ ) correspond well to the concentrations typical of volcanic-arc granites (Fig. 8, Pearce et al. 1984).
Tab. 7 Electron microprobe analyses from biotite (wt. \% and apfu based on 22 O)

\begin{tabular}{|c|c|c|c|c|c|c|c|}
\hline Sample & 1 & 2 & 3 & 4 & 5 & 6 & 7 \\
\hline $\mathrm{SiO}_{2}$ & 35.97 & 35.52 & 35.86 & 35.52 & 36.58 & 36.26 & 36.04 \\
\hline $\mathrm{TiO}_{2}$ & 3.60 & 3.69 & 3.36 & 3.41 & 3.23 & 3.44 & 3.38 \\
\hline $\mathrm{Al}_{2} \mathrm{O}_{3}$ & 14.41 & 14.40 & 14.39 & 14.57 & 15.05 & 14.74 & 14.58 \\
\hline $\mathrm{BaO}$ & 0.37 & 0.56 & 0.00 & 0.00 & 0.16 & 0.00 & 0.13 \\
\hline $\mathrm{FeO}$ & 23.97 & 23.96 & 24.07 & 23.88 & 22.75 & 23.05 & 23.11 \\
\hline $\mathrm{MnO}$ & 0.39 & 0.46 & 0.36 & 0.40 & 0.41 & 0.40 & 0.38 \\
\hline $\mathrm{MgO}$ & 8.34 & 8.28 & 8.29 & 8.31 & 8.77 & 8.70 & 8.63 \\
\hline $\mathrm{CaO}$ & 0.00 & 0.05 & 0.13 & 0.06 & 0.06 & 0.08 & 0.00 \\
\hline $\mathrm{Na}_{2} \mathrm{O}$ & 0.07 & 0.06 & 0.04 & 0.00 & 0.05 & 0.04 & 0.06 \\
\hline $\mathrm{K}_{2} \mathrm{O}$ & 9.62 & 9.49 & 9.26 & 9.53 & 9.73 & 9.71 & 9.38 \\
\hline Total & 96.74 & 96.37 & 95.76 & 95.68 & 96.79 & 96.42 & 95.69 \\
\hline $\mathrm{Si}$ & 5.579 & 5.543 & 5.592 & 5.551 & 5.612 & 5.592 & 5.604 \\
\hline $\mathrm{Al}^{\mathrm{IV}}$ & 2.421 & 2.457 & 2.408 & 2.449 & 2.388 & 2.408 & 2.396 \\
\hline $\mathrm{Al}^{\mathrm{VI}}$ & 0.213 & 0.191 & 0.236 & 0.235 & 0.334 & 0.271 & 0.275 \\
\hline $\mathrm{Ti}$ & 0.420 & 0.433 & 0.394 & 0.401 & 0.373 & 0.399 & 0.395 \\
\hline $\mathrm{Fe}$ & 3.109 & 3.127 & 3.139 & 3.121 & 2.919 & 2.973 & 3.005 \\
\hline Mn & 0.051 & 0.061 & 0.048 & 0.053 & 0.053 & 0.052 & 0.050 \\
\hline $\mathrm{Mg}$ & 1.928 & 1.926 & 1.927 & 1.936 & 2.006 & 2.000 & 2.000 \\
\hline $\mathrm{Ca}$ & 0.000 & 0.008 & 0.022 & 0.010 & 0.100 & 0.013 & 0.000 \\
\hline $\mathrm{Na}$ & 0.021 & 0.018 & 0.012 & 0.000 & 0.015 & 0.012 & 0.018 \\
\hline $\mathrm{K}$ & 1.903 & 1.889 & 1.842 & 1.900 & 1.904 & 1.910 & 1.861 \\
\hline $\mathrm{Z}$ & 8 & 8 & 8 & 8 & 8 & 8 & 8 \\
\hline $\mathrm{Y}$ & 5.722 & 5.738 & 5.743 & 5.746 & 5.685 & 5.695 & 5.726 \\
\hline $\mathrm{X}$ & 1.925 & 1.916 & 1.876 & 1.910 & 1.929 & 1.936 & 1.879 \\
\hline $\mathrm{XMg}$ & 0.383 & 0.381 & 0.380 & 0.383 & 0.407 & 0.402 & 0.400 \\
\hline
\end{tabular}

Nr. 1-5, J/10/93: amphibole-biotite granodiorite (Rena suite): 1-2 large grains - core; 3-4 biotite associated with amphibole -core

Nr. 5-7, J/5/93: fine-grained, grey biotite granodiorite (Tetčice suite) 

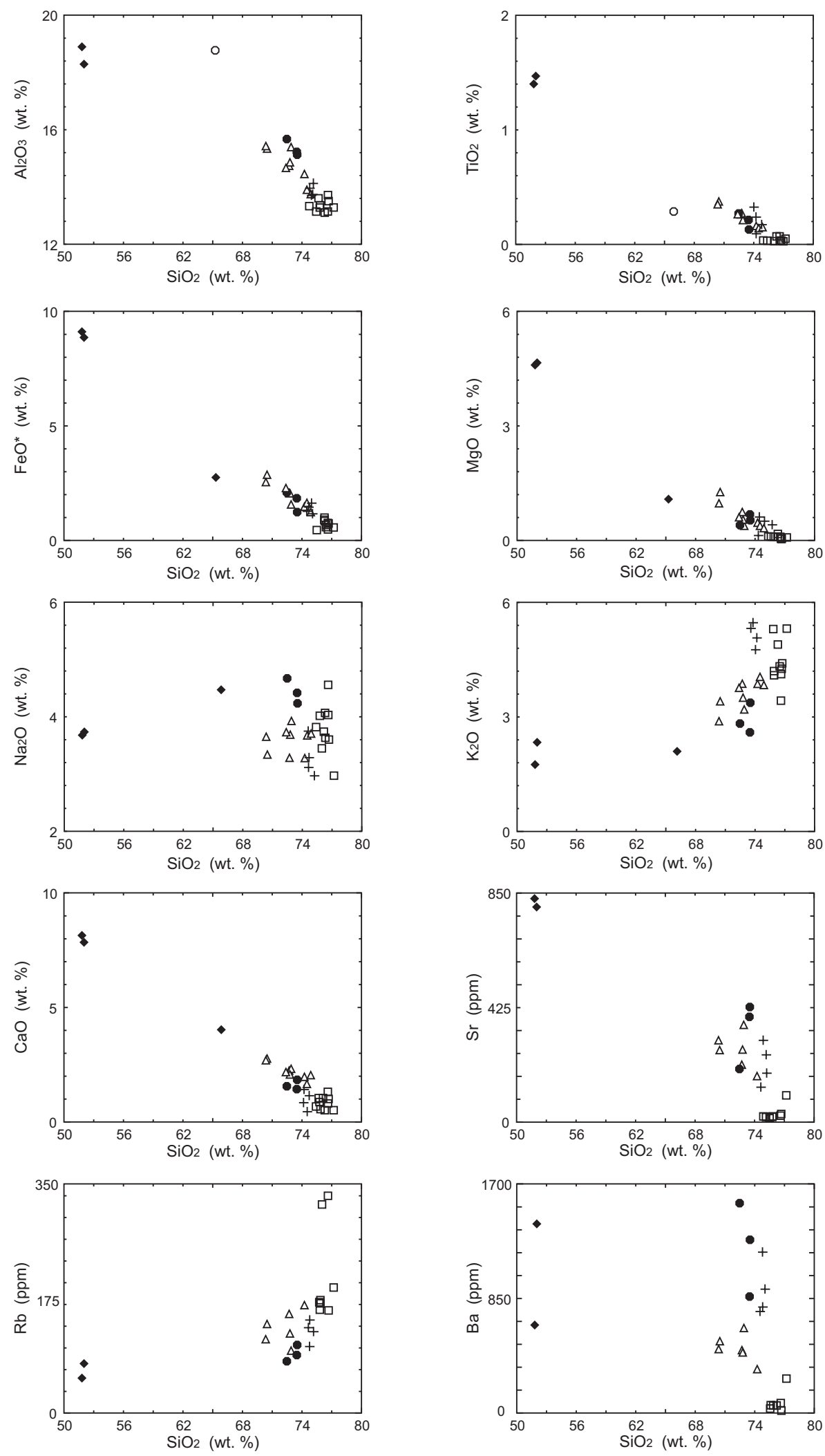

Fig. 7 Variation diagrams of $\mathrm{SiO}_{2}$ vs. selected major- and trace-elements for granitoids from the Western Granitoid Complex.

Rena suite;

Tetčice suite - grey granites;

Tetčice suite - diorites, tonalites

+ Tetčice suite - red granites; $\square$ Hlína suite 

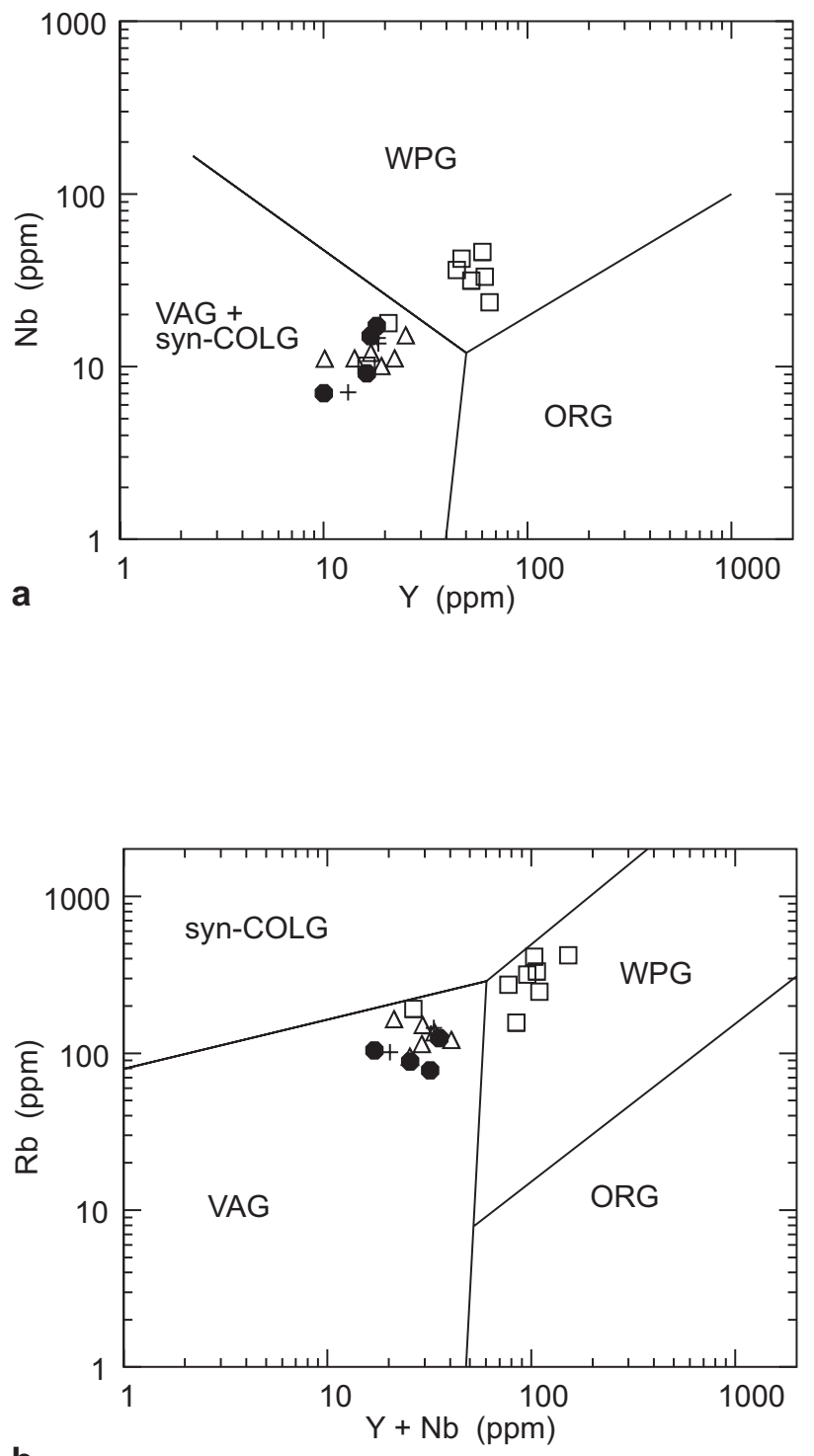

b

Fig. $8 \mathrm{Nb}-\mathrm{Y}$ and $\mathrm{Rb}-\mathrm{Nb}+\mathrm{Y}$ diagrams after Pearce et al. (1984), for granitoids from the Western Granitoid Complex, symbols as in Fig. 7. The granitoids from the Rena and Tetčice suites plot in the field of Volcanic Arc Granites, the garnet-bearing granites from the Hlína suite in the field of Within Plate Granites. between diorites and granites as a product of their mutual interaction. Sharp contacts between both rock types are more seldom. The dioritic enclaves with a sharp contact to the host granite do not exceed $2 \mathrm{~m}$ in size, and are usually partly rounded, which indicates some transport of the already solidified diorite by the granitic magma (Didier 1987). Apart from dioritic enclaves, the granites host a broad spectrum of metasedimentary xenoliths, e.g. gneisses, migmatites, and calc silicates. The size of xenoliths varies greatly. The smallest can be observed only microscopically as biotite + plagioclase spots several millimetres across set in the light-coloured granites. The maximum size of roof pendants ranges up to $3 \mathrm{~km}$. The large metasedimentary xenoliths are often surrounded by a zone of intense migmatitization. The presence of numerous enclaves and hybrids developing around them induces a strong inhomogeneity of the host rocks, first noted by Suess (1903).

The diorites are amphibole- or biotite-amphibole-bearing, medium- to coarse-grained, dark-grey to green-grey rocks. They consist of simply zoned plagioclase $\left(\mathrm{An}_{50}\right.$ core, $\mathrm{An}_{40}$ rim, Tab. 1), unzoned amphibole (hornblende-edenite; Tab. 2, Fig. 3), biotite, quartz, ilmenite with titanite overgrowths, zircon and apatite. The cores of plagioclase are usually strongly altered. The alteration products include white mica, epidote and sodic plagioclase. Since no relics of pyroxene were found in the amphibole, and amphibole is enriched in both $\mathrm{TiO}_{2}$ (1.06-1.48 wt. \%) and $\mathrm{K}_{2} \mathrm{O}(0.69-0.76 \%)$, its origin is probably magmatic. Some amphibole grains are rimed by biotite. Titanites replacing ilmenite differ chemically from those from granodiorites. They are enriched in $\mathrm{TiO}_{2}\left(38.4\right.$ wt. \%) and depleted in $\mathrm{Al}_{2} \mathrm{O}_{3}(1.44 \%$, Tab. 8). Apatite appears in two morphologically different forms. It forms generally long prismatic crystals (L: $\mathrm{W}>20$ ); the small diorite enclaves in the granodiorites contain short prismatic $(\mathrm{L}: \mathrm{W}=4)$ apatite generation in addition. The latter, short prismatic crystals are typical of the host Tetčice granitoids. The common occurrence of both apatite types in the dioritic enclaves indicates magma mixing between diorite and granodiorite (Didier
Tetčice suite consists of three main types of plutonic rocks: (1) biotite-bearing, fine-grained granodiorites, which are, close to the contact with Metabasite Zone, rimmed by (2) coarse-grained red granites. Lastly, (3) biotite-amphibole diorites form xenoliths in both granite types. Normally the contacts between granites and diorites are transitional; occasionally tonalites appear at the contact
Tab. 8 Electron microprobe analyses from titanite (1-5) and ilmenite (6)

\begin{tabular}{lcccccccc}
\hline Sample & $\mathrm{SiO}_{2}$ & $\mathrm{Al}_{2} \mathrm{O}_{3}$ & $\mathrm{MgO}$ & $\mathrm{TiO}_{2}$ & $\mathrm{CaO}$ & $\mathrm{FeO}$ & $\mathrm{MnO}$ & Total \\
\hline 1 & 30.7 & 5.01 & 0.00 & 32.9 & 28.4 & 0.66 & 0.06 & 97.71 \\
2 & 30.3 & 4.21 & 0.00 & 33.7 & 28.2 & 0.70 & 0.08 & 97.16 \\
3 & 30.2 & 3.04 & 0.00 & 35.1 & 27.9 & 0.55 & 0.12 & 96.87 \\
4 & 30.6 & 4.39 & 0.03 & 33.4 & 28.0 & 0.71 & 0.06 & 97.48 \\
5 & 30.0 & 1.44 & 0.00 & 38.4 & 28.4 & 0.57 & 0.06 & 98.79 \\
6 & 0.00 & 0.00 & 0.16 & 52.7 & 0.05 & 45.70 & 2.37 & 101.01 \\
\hline
\end{tabular}

Nr. 1-2, J/10/93: amphibole-biotite granodiorites (Rena suite)

Nr. 3-4, J/5/93: fine-grained, grey biotite granodiorites (Tetčice suite)

Nr. 5-6, J/14b/93: biotite-amphibole diorites (Tetčice suite) 
1987). The diorites are relatively basic $\left(\mathrm{SiO}_{2}=51.5\right.$ wt. \%) but alumina rich (18.5\%). The $\mathrm{MgO}(4.6 \%), \mathrm{Cr}$ (c. $115 \mathrm{ppm})$, and $\mathrm{V}$ (c. $170 \mathrm{ppm})$ contents are rather low. The $\mathrm{TiO}_{2}$ (1.4 wt. \%), $\mathrm{P}_{2} \mathrm{O}_{5}(0.44-0.64 \%), \mathrm{K}_{2} \mathrm{O}(2 \%), \mathrm{Rb}$ (64 ppm), Zr (200 ppm), Nb (23 ppm) and $\mathrm{Y}(33 \mathrm{ppm})$ are comparatively high (Tab. 3 ).

The granitoids of the Tetčice suite are extremely inhomogeneous. Two principal types of granites were recognized within this suite - (1) grey, fine-grained biotitebearing granodiorites, (2) red, coarse-grained granites. The contact between both types could not be observed directly in the field. Locally mapped zone between both types, several hundred meters thick, of pink porphyritic biotite-bearing granodiorites-granites renders the transitional contact more likely. The grey granodiorites consist of subhedral plagioclase (33-52 vol. \%), subhedral to anhedral K-feldspar (9-22\%), anhedral quartz (30-43\%), biotite (3-7\%), with accessoric zircon, apatite, and titanite (Tab. 5). White mica, chlorite, and epidote are the secondary phases. The smaller size with generally sub- to anhedral habit of the rock-forming minerals and the absence of amphibole are the main differences compared to the Rena suite granodiorites.

Plagioclases are typically oscillatory-zoned (Tab. 1). The central zone is usually altered. It consists mostly of oligoclase $\left(\mathrm{An}_{14}\right)$, white mica (muscovite with 2-24\% of paragonite molecule, Tab. 4), epidote and zoisite (Tab. 9). The unaltered zone between core and rim consists mostly of oligoclase $\left(\mathrm{An}_{22-24}\right)$. Albite $\left(\mathrm{An}_{3}\right)$ was found as a very thin zone at the rim. The $\mathrm{K}_{2} \mathrm{O}$ content in the plagioclase $(0.07-0.25$ wt. \%) is low compared with the Rena suite $(0.13-0.40 \%)$.

Tab. 9 Electron microprobe analyses from epidote (1-2) and zoisite (3)

\begin{tabular}{lrrr}
\hline Sample & \multicolumn{1}{c}{1} & \multicolumn{1}{c}{2} & \multicolumn{1}{c}{3} \\
\hline $\mathrm{SiO}_{2}$ & 38.10 & 37.90 & 39.50 \\
$\mathrm{Al}_{2} \mathrm{O}_{3}$ & 26.10 & 25.80 & 32.80 \\
$\mathrm{FeO}$ & 8.60 & 9.00 & 0.91 \\
$\mathrm{MnO}$ & 0.38 & 0.31 & 0.10 \\
$\mathrm{CaO}$ & 23.10 & 23.10 & 24.50 \\
\hline Total & 96.34 & 96.08 & 97.74 \\
\hline
\end{tabular}

J/5/93 fine-grained, grey biotite granodiorite (Tetčice suite)

The perthitic K-feldspar frequently exhibits crosshatched twinning and hosts strongly altered plagioclases, biotite, chlorite and quartz. Myrmekite appears along the contact between plagioclase and K-feldspar locally. The results of the EMP analyses are listed in Tab. 6. The major differences in contrast to the Rena suite are a higher $\mathrm{BaO}(0.74-0.89$ wt. \%) and $\mathrm{CaO}(0.04-0.13 \%)$ concentration.

Biotite forms small subhedral grains, which are often replaced by chlorite. The alteration is usually stronger at the rim. The fresh biotite is not zoned (Tab. 7). Compared with biotite from the Rena suite it is enriched in $\mathrm{Al}_{2} \mathrm{O}_{3}\left(14.58-15.05\right.$ wt. \%) and depleted in $\mathrm{FeO}_{\text {tot. }}$ $(22.75-23.11 \%)$ with $\mathrm{BaO}(0-0.16 \%)$. The chloritization is accompanied by a decrease in $\mathrm{SiO}_{2}, \mathrm{~K}_{2} \mathrm{O}, \mathrm{TiO}_{2}$ and by an increase in $\mathrm{Al}_{2} \mathrm{O}_{3}, \mathrm{MgO}, \mathrm{FeO}$, and $\mathrm{H}_{2} \mathrm{O}$.

The zircon morphology reflects the inhomogeneous nature of the rock once more (Fig. 6). The presence of rounded zircon grains reveals an assimilation of metasedimentary rocks. The igneous zircons with a crystal habit display three maxima if plotted in a typology diagram (Pupin 1980). The maximum in the upper left corner (H, L1) is typical of S-type granites. These zircons probably originated during crystallization of the granitic melt. The maxima approximately in the centre (S19) and on the right side of the diagram (P2, P3), may indicate a contamination of the granitic magma by a diorite, because zircons with P2, P3 forms are typical of dioritic xenoliths.

The granodiorites of the Tetčice suite are, from the geochemical point of view (Tab. 3), enriched in $\mathrm{Al}_{2} \mathrm{O}_{3}$ (14.96-15.64 wt. \%), $\mathrm{Na}_{2} \mathrm{O}(4.23-4.66 \%)$ and $\mathrm{Ba}(849-$ $1554 \mathrm{ppm})$, as well as depleted in $\mathrm{CaO}(1.24-1.84 \%)$ and $\mathrm{Sr}$ (197-427 ppm) when compared with similar granodiorites of the Rena suite. The alumina saturation index (ASI) higher than $1.1(1.14-1.20)$ indicates a S-type affinity for these granodiorites. The major elements do not exhibit clear trends in the variation diagrams (Fig. 7). The $\mathrm{Mg}-\mathrm{Fe}$ and $\mathrm{K}-\mathrm{Rb}$ pairs do not show any systematic variation either. The concentrations of the HFSE (mostly $\mathrm{Nb}, \mathrm{Zr}$, and, to a lesser degree, Ti) are variable and depend directly on the biotite contents. The biotite-rich samples exhibit elevated concentrations of $\mathrm{Nb}(15 \mathrm{ppm})$, $\mathrm{Zr}$ (324 ppm), and $\mathrm{TiO}_{2}(0.27$ wt. \%). The lower values $\left(\mathrm{Nb}=9 \mathrm{ppm}, \mathrm{Zr}=80-147 \mathrm{ppm}, \mathrm{TiO}_{2}=0.13-0.21\right)$ are typical of biotite-poor members.

The red granites form mostly continuous rim along the western margin of the Metabasite Zone (Fig. 2). These granites are usually coarser grained than the grey granodiorites. Dykes of this granite penetrated the Metabasite Zone locally; some of these have a subvolcanic character with corroded quartz phenocrysts in a very fine-grained matrix. Remarkable attributes are, apart from the red colour, higher modal contents of K-feldspar (32-46 \% vs. $23-26 \%$ in the grey granodiorites) and mostly a complete alteration of biotite to chlorite.

Their modal composition is - K-feldspar (32-46 vol. \%), plagioclase (15-28\%), quartz (22-39\%), chlorite $(1-5 \%$ ), magnetite-haematite (up to $2 \%$ ), remnants of biotite, white mica, zircon, and apatite (Tab. 5). The anhedral to subhedral, perthitic K-feldspars are up to $2 \mathrm{~cm}$ long. The finely dispersed hematite gives the reddish colour to the feldspar. The perthites occupy up to $40 \%$ of the individual crystals. Plagioclases from coarse perthites are 
usually strongly altered. K-feldspars from red granites are depleted in $\mathrm{BaO}(0.26-0.27$ wt. \%) and enriched in $\mathrm{FeO}$ (0.06-0.07 wt. \%) if compared with grey granodiorites.

Plagioclases are significantly smaller than K-feldspars. Their size is about $8 \mathrm{~mm}$. Plagioclase inclusions in K-feldspar are abundant, and sometimes represent the most common form of plagioclase in the rock. Rapakivi texture (K-feldspar rimmed by plagioclase) was observed locally. Plagioclase $\left(\mathrm{An}_{4-8}\right)$ is commonly replaced by Fe-rich muscovite (Tab. 4), and pure albite $\left(\mathrm{An}_{0.7-1.5}\right)$. The $\mathrm{Ca}$ and $\mathrm{Al}$ released by decomposition of plagioclase are accommodated in epidote, forming veins cutting the rock. Chlorite originated from biotite, and reasonably fresh biotite could be found as relics in chlorite only.

The red granites are, compared with the grey granodiorites from Tetčice suite, highly enriched in $\mathrm{SiO}_{2}$ (73.45-74.21 wt. \%), and $\mathrm{K}_{2} \mathrm{O}$ (4.68-5.13\%), but only slightly in $\mathrm{Rb}(87-144 \mathrm{ppm})$, and depleted in $\mathrm{MgO}(0.23-$ $0.51 \%), \mathrm{Al}_{2} \mathrm{O}_{3}(13.62-13.92 \%), \mathrm{CaO}(0.36-1.35 \%)$, with $\mathrm{BaO}$ (779-846 ppm). The concentrations of HFSE - Zr (109-171), Y (13-18 ppm) and $\mathrm{Nb}$ (13-18 ppm) are similar (Tab. 3, Fig 8).

Hlina suite is represented by irregular intrusions and dykes of felsic $\left(\mathrm{SiO}_{2}>75\right.$ wt. \%), K-rich, fine-grained, garnet- and/or biotite-bearing granites. Some dykes grade into a coarse-grained facies in their central parts. Relatively large intrusions were found only within the Tetčice suite; dykes however cut both the Tetčice and Rena suites. Several metres wide alteration zones, marked by reddish haloes, are developed along the contact between dykes and surrounding rocks.

This granite consists of anhedral quartz (26-35 vol. \%), subhedral, zoned (core $-\mathrm{An}_{15}, \mathrm{rim}-\mathrm{An}_{8}$ ) plagioclase (25-30\%), and subhedral to anhedral K-feldspar (35-41\%, Tab. 5). Some plagioclases are rimmed by granophyre. Minor to accessory minerals include garnet ( $1 \%)$, biotite $(0.5-5 \%)$, magnetite, epidote, $\mathrm{Nb}$, Y-rich zircon $\left(\leq 6.60 \mathrm{Nb}_{2} \mathrm{O}_{5}\right)$, cheralite, $\mathrm{Nb}, \mathrm{Ta}$, Al-rich titanite, plumbopyrochlore and karnarsurtite (Leichmann et al. 1999). White mica (1-2\%), and chlorite $(<1 \%$, Tab. 5) are of secondary origin. Compared with the other granites from the Brno Batholith, K-feldspars of the Hlína suite (Tab. 6) are depleted in $\mathrm{Na}_{2} \mathrm{O}(0.27-0.32$ wt. \%) and devoid of $\mathrm{Ba}$ (whole-rock analyses yielded 14-46 ppm Ba only). K-feldspars exhibit sector zoning if observed in cathodoluminescence. Oscillatory-zoned spessartite-almandine is a typical accessory mineral $\left(\mathrm{Sps}_{48-46}, \mathrm{Alm}_{36-35}\right.$, And $_{12-11}, \mathrm{Grs}_{7-4}, \operatorname{Prp}_{4-1}$; Tab. 10). Its most prominent feature is a high concentration of yttrium (2.16 wt. \% $\mathrm{Y}_{2} \mathrm{O}_{3}$ ) at the rim.

The felsic nature of the rock is reflected in the high $\mathrm{SiO}_{2}$ (74.9-75.9 wt. \%; Tab. 3), $\mathrm{K}_{2} \mathrm{O}$ (4.11-4.29\%), $\mathrm{Na}_{2} \mathrm{O}$ (3.73-4.18\%), and low $\mathrm{FeO}(0.79-0.90 \%), \mathrm{MgO}(0.02-$ $0.03 \%), \mathrm{CaO}(0.61-1.02 \%)$, and $\mathrm{TiO}_{2}(0.02-0.04 \%)$.
Tab. 10 Electron microprobe analyses from garnet (wt. \% and apfu based on $12 \mathrm{O}$ )

\begin{tabular}{lrrr}
\hline Sample & \multicolumn{1}{c}{1} & \multicolumn{1}{c}{2} & \multicolumn{1}{c}{3} \\
\hline $\mathrm{SiO}_{2}$ & 36.09 & 35.83 & 34.88 \\
$\mathrm{TiO}_{2}$ & 0.22 & 0.09 & 0.26 \\
$\mathrm{Al}_{2} \mathrm{O}_{3}$ & 18.21 & 18.43 & 17.62 \\
$\mathrm{Cr}_{2} \mathrm{O}_{3}$ & 0.00 & 0.00 & 0.00 \\
$\mathrm{Y}_{2} \mathrm{O}_{3}$ & 0.73 & 0.31 & 2.16 \\
$\mathrm{FeO}$ & 18.05 & 17.94 & 18.12 \\
$\mathrm{MnO}$ & 19.40 & 19.27 & 19.95 \\
$\mathrm{MgO}$ & 0.28 & 0.29 & 0.85 \\
$\mathrm{CaO}$ & 5.87 & 6.12 & 3.88 \\
\hline $\mathrm{Total}$ & 98.83 & 98.27 & 95.56 \\
\hline $\mathrm{Alm}$ & 0.355 & 0.352 & 0.362 \\
$\mathrm{Sps}$ & 0.458 & 0.454 & 0.483 \\
$\mathrm{Prp}$ & 0.012 & 0.012 & 0.036 \\
$\mathrm{Grs}$ & 0.070 & 0.082 & 0.004 \\
$\mathrm{Adr}$ & 0.106 & 0.100 & 0.115 \\
\hline
\end{tabular}

Nr. 1-3, J/21/93: garnet-bearing leucogranites (Hlína suite)

The low ASI (1.02-1.07), disregarding the high $\mathrm{SiO}_{2}$ contents, indicates an I-type affinity of the Hlína suite. A high degree of fractionation is indicated by fairly low $\mathrm{mg} \#(2-7), \mathrm{K} / \mathrm{Rb}(228-103)$, and very high $\mathrm{K} / \mathrm{Ba}(742-$ $2544)$ ratios. The elevated amount of $\mathrm{MnO}(0.04-0.11 \%)$ and high content of Y (23-58 ppm) correspond with their high concentrations in garnet. $\mathrm{The} \mathrm{Nb}(19-51 \mathrm{ppm})$ and $\mathrm{Rb}$ (156-311 ppm) concentrations are elevated; $\mathrm{Zr}$ (72-79 ppm), $\mathrm{Sr}$ (16-30 ppm), and $\mathrm{Ba}(14-46 \mathrm{ppm})$ contents are lower than in the other Brno Batholith granitoids. The concentration of LREE is very low, whereas concentration of HREE is unusually high (Fig. 9, Tab. 3). The granites plot, based on their high concentrations of $\mathrm{Y}$, $\mathrm{Nb}$, and $\mathrm{Rb}$, in the field of WPG (Within-Plate Granites) of Pearce et al. (1984) (Fig. 8).

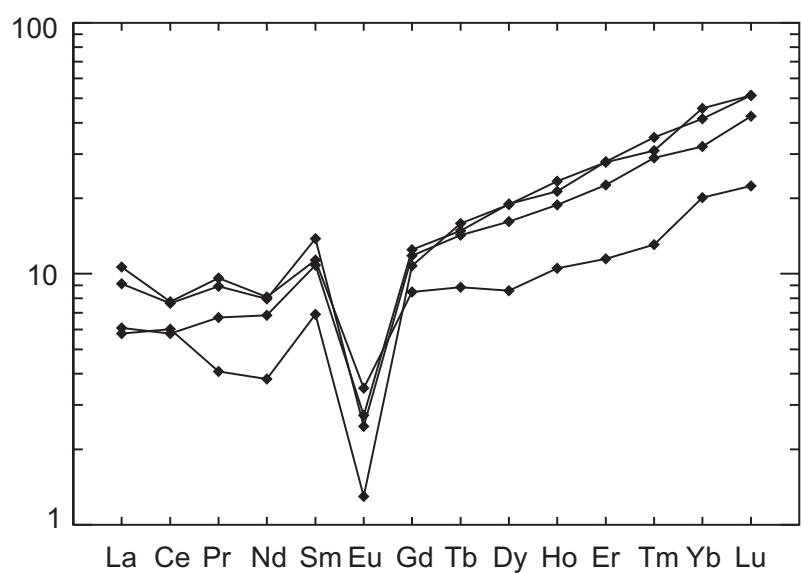

Fig. 9 Chondrite-normalized REE patterns (Sun 1980) for garnet-bearing granites, Hlína suite. 


\section{Discussion}

\subsection{Interpretation of individual rock units}

\subsubsection{Metabasite Zone}

The sequence of ultramafic, plutonic and volcanic rocks from the Metabasite Zone resembles most likely an ophiolite succession (Best and Christiansen 2001). Even though the sheeted-dyke complex has not been observed yet, the sequence is rather complete ranging from ultramafic rocks (cumulates) to NMORB-like volcanic rocks. All members of the ophiolite suite underwent a similar metamorphic evolution, starting with greenschist-, passing to lower amphibolite- and ending with retrograde, lower greenschist-facies conditions. This style of metamorphic evolution could be compared with ocean-floor metamorphism. On the other hand, no relics of high-pressure overprinting, which could indicate subduction processes, were recognised in the Metabasite Zone. This metamorphic evolution markedly differs from typical simple lower greenschist-facies overprinting of surrounding granites and diorites. Many plutonic rocks from the Western Granitoid Zone are even fresh, without any traces of alteration or metamorphic overprinting. This fact argues strongly for a genetic relationship between the plutonic and volcanic sequences of the ophiolite, indicating their common origin.

Even though the lithology and metamorphic evolution of the Metabasite Zone is reasonably well known and comparable with modern ophiolite complexes, the tectonic interpretation of this ophiolite complex is less well constrained. Its tilted position, metamorphic evolution and relative small regional extent indicate that the Metabasite Zone represents only a small piece of an ophiolite complex, which could have been obducted onto an ancient continental or arc crust. However, the nature and character of this ancient crust, its relation to the granites surrounding the Metabasite Zone at the present-day erosion level, which are at least $150 \mathrm{Ma}$ younger, as well as many other features that influenced the post-magmatic evolution of the ophiolites remain unknown. The same is valid for the petrotectonic interpretation of this zone. The metabasalts range, apart from post-magmatic alteration affecting certainly LILE, from typical depleted MORB compositions to enriched types. The high positive initial $\varepsilon_{\mathrm{Nd}}$ values $(+6.7$ to $+7.4-$ Finger et al $2000 \mathrm{~b} ;+5.2$ to +8.4 - Janoušek and Hanžl 2000) confirm a depleted-mantle source for the NMORB-like basalts.

While the more depleted rocks seem to prevail in the South, the more enriched metabasic rocks occur in the North (see also Janoušek and Hanžl 2000). This distribution argues for a possible systematic change in the mantle source composition, becoming less depleted northwards. An alternative view is an assumption that the intraplate basalts may overlay locally the depleted MORB. The rhyolites, given to the small size of the available dataset, are difficult to interpret. They might represent strongly fractionated members of the ophiolite suite or may be interpreted as volcanic equivalents of the plutonic trondhjemites. The later model is supported by their chemistry, resembling trondhjemites, as well as by high $\varepsilon_{\mathrm{Nd}}(+6.8$, Finger et al 2000b). Anyhow, apparently not all rhyolites from the Metabasite Zone belong to the ophiolite sequence. Some rhyolite dykes, especially those enriched in potassium, were probably associated with the intrusion of the later granites.

The chemistry of the basalts, rhyolites and trondhjemites indicates three possible environments - ocean floor, volcanic arc, and within-plate setting. At least three arguments make the interpretation of geochemical data relative. (1) It is not clear, to which extent were their trace-element signatures influenced by postmagmatic processes. This concerns even concentrations of HFSE, which are the main argument for the petrotectonic interpretations. The age of the ophiolites is very high $(>725$ Ma, Finger et al 2000). The studied ophiolite complex was formed just close in time to the beginning of the modern plate tectonics (Goodwin 1996). Thus the simplistic extrapolation of geochemical data, which were obtained from recent or at least Phanerozoic settings, may be problematic for such old complexes. (2) Fragment only, from probably much larger ophiolite complex, is accessible for the study today. It is not clear, how representative this fragment is, and why just this fragment survived. (3) Anyhow, even the lithology and chemistry of the studied ophiolite complex - the Metabasite Zone - indicate that it did not originate on the typical ocean ridge. Its genesis could be rather envisaged in an environment, which would resemble a modern back-arc basin or a supra-subduction zone environment.

\subsection{Granites}

\subsubsection{Rena suite}

A close relation between the geochemistry, mineralogy and zircon typology was observed within this suite. The amphibole-rich granodiorites are enriched in $\mathrm{MgO}, \mathrm{TiO}_{2}$, and depleted in $\mathrm{Na}_{2} \mathrm{O}$. Moreover, they exhibit higher $\mathrm{Mg}$ / Fe ratios (0.32-0.44) compared with the biotite-rich granites of the same suite $(\mathrm{Mg} / \mathrm{Fe}=0.24-0.26)$. The decrease in $\mathrm{Mg} / \mathrm{Fe}$ from granodiorites to granites, accompanied by a decrease in $\mathrm{V}, \mathrm{Cr}$, and $\mathrm{Ni}$, indicates an important role for the amphibole fractionation in the evolution of the Rena suite. The assessment of the role for both feldspars in the fractionation process remains much more uncertain. The decreasing $\mathrm{Ba}$ contents and increasing $\mathrm{K} / \mathrm{Rb}$ ratios 
during the evolution of a granitic magma are commonly used as a fingerprint of the K-feldspar fractionation (Best and Christiansen 2001). However, in the present case no systematic variation in $\mathrm{Ba}$ contents or $\mathrm{K} / \mathrm{Rb}$ ratios was observed in the whole-rock chemistry between the amphibole-biotite granodiorites and biotite granites. This is probably due to the fact that biotite contains even more $\mathrm{BaO}(0.37-0.56 \%)$ than K-feldspar (0.19-0.27\%), and $\mathrm{Ba}$, together with potassium, disappeared almost completely from biotite during chloritization. This later chloritization affected the biotites from the Rena suite to various degrees (10-100\%). Therefore, it is very likely, that the concentrations of the LILE (especially Ba and $\mathrm{K}$ ) are affected by a late-stage alteration, mainly by chloritization of biotite.

The evolutionary trend from granodiorites to granites is reflected in switch in zircon typology approximately from S24 to P3 (Fig. 6). Taken together, the mineral composition of the amphibole-biotite granodiorites and biotite granites, the occurrence of oscillatory zoned plagioclases, mostly linear differentiation trends, decreasing $\mathrm{Mg} / \mathrm{Fe}$ ratios from granodiorites to granites, an aluminum saturation index below 1.1, a low content of HFSE, as well as the evolutionary trend of zircon morphology (Pupin 1985) are indicative for I-type granitoids (Champion and Chappell 1992), and suggest that both granite types may be connected by fractional crystallization processes. The concentration of trace elements is comparable to granites derived at volcanic arcs. However, the lack of precise geochronological and isotopic data makes a more detailed genetic interpretation for this suite speculative.

\subsubsection{Tetčice suite}

From the geophysical point of view, the Tetčice suite is accompanied by a positive gravity anomaly. The difference, compared to the Rena suite, is $+20 \mathrm{mGal}$. This observation does not agree with the surface situation, as the granites from the Rena suite are denser (2.66-2.67 $\left.\mathrm{g} / \mathrm{cm}^{3}\right)$ when compared with the Tetčice suite $\left(2.62 \mathrm{~g} / \mathrm{cm}^{3}\right.$; Skácelová and Weiss 1978). The Rena suite should exhibit a positive gravimetrical anomaly, but this is not the case. This discrepancy indicates that the diorites, which are dense enough $\left(2.86 \mathrm{~g} / \mathrm{cm}^{3}\right)$ to account for such an anomaly, are widespread under the current exposure level, and are covered only by a thin layer of granitoids.

The geochemical features of the granitoids of the Tetčice suite, such as the peraluminous nature (ASI = 1.14-1.20), Ca-poor character, as well as the mineral composition, especially the presence of Al-rich biotite as a dominant dark mineral, allow us to interpret the Tetčice granitoids as being of S-type character (Clarke 1981; Chappell and White 1992). Barbarin (1996) distinguished two main groups among the S-type granitoids. The first are muscovite-bearing granitoids generated through wet anatexis of crustal rocks. The second, formed by biotitecordierite or biotite-bearing granitoids, originated as a consequence of a fairly dry anatexis of crustal material caused by an intrusion of a hot basic melt into the metasedimentary crust. Similar processes were invoked by Williamson at al. (1992), with Barton and Sidle (1993) to explain the origin of biotite-bearing peraluminous granitoids. Many features like (1) shared occurrence of metasedimentary and mafic inclusions in the granodiorites (Didier 1987); (2) presence of several types of zircon and apatite; (3) large extent of migmatitization and anatexis of enclosed metasedimentary rocks; (4) magma mixing phenomena indicative of an interaction between acid and basic magmas; and (5) gravimetric evidence, suggest the presence of more dense basic rocks at depth, below the granitoids. Especially the last feature indicates that the origin of the Tetčice suite granitoids can be best explained by an intrusion of hot basic magma into the metasedimentary crust, triggering a large-scale melting. Nevertheless it is necessary to take into account that the late-stage alteration - invoking mineralogical changes, like decomposition of biotite and calcic plagioclase accompanied by the formation of new K- (white mica), and $\mathrm{Ca}$ - (epidote, zoisite, titanite) phases, may have slightly changed the primary whole-rock chemical compositions. The decomposition of biotite was recognized as the initial reaction, accompanied by the release of potassium. It caused a succession of following reactions and, consequently, a redistribution of $\mathrm{Ca}, \mathrm{K}$, and $\mathrm{Na}$ (decomposition of Ca-rich cores of plagioclases, formation of white mica, $\mathrm{K}$-feldspar, albite, zoisite, etc.). Realistic seems to assume that these reactions were initiated by an influx of aqueous fluids with only limited changes of the wholerock chemistry. An intense redistribution of elements like $\mathrm{K}, \mathrm{Na}$, and $\mathrm{Ca}$ may explain the occurrence and origin of copious myrmekites (Garcia et al. 1996) observed in the Tetčice granitoids.

The red granites could probably represent more fractionated, marginal facies, strongly influenced by the fluid migration. Disturbed concentrations of mainly LILE, induced by alteration, as well as the absence of isotopic data, do not allow the verification of this scenario by precise geochemical data.

\subsubsection{Hlína suite}

Some accessory (primary to secondary) minerals found in this felsic granite correspond to peralkaline or hyperalkaline rocks: e.g., Y, Na-rich spessartine-almandine $(\leq 2.16$ $\left.\mathrm{Y}_{2} \mathrm{O}_{3}, \leq 0.25 \mathrm{Na}_{2} \mathrm{O}\right), \mathrm{Nb}$, Y-rich zircon, $\mathrm{Nb}$, Ta, Al-rich titanite, plumbopyrochlore and karnarsurtite are in a contrast with the relatively high ASI (1.02-1.07). This may be a result of anhydrous crystallization of felsic, REE-, 
$\mathrm{Nb}-$, F-rich and Fe-, Mg-, Ca-, Ti-, P-poor, probably even highly fractionated magma, which prevented early precipitation of alkali pyroxenes and amphiboles, allanite or REE-phosphates (Leichmann et al. 1999). This type of granite strongly differs, by its mineralogy and geochemistry, from all other S- or I-type granites known from Brunovistulicum. The rocks are evidently anhydrous, anorogenic and, at least accessory minerals, indicate their alkaline affinity. Clearly, a distinct A-type component (Pitcher 1997) is apparent in this type of granite.

\subsection{Geotectonic development}

The rock association exposed in Brno Batholith is fairly variegated. The oldest member is evidently the Ophiolite Belt. Our petrological and geochemical data indicate, in accordance with Finger et al. (2000a) that it originated in supra-subduction zone environment. This, at least 725 old, already metamorphosed ophiolite was intruded by variable granite complexes at approximately $600 \mathrm{Ma}$. The Eastern Granitoid Complex (part of the Slavkov Terrane sensu Finger et al. 2000a) intruded the ophiolite in the hanging-wall. It represents monotonous, I-type, amphibole- to biotite-bearing suite of quartz diorites-tonalites-granodiorites. Petrologic (Štelcl and Weiss 1986; Hanžl and Melichar 1997) as well as isotopic data (Finger et al. 2000b) indicate an origin in a primitive volcanicarc environment. The Western Granitoid Complex (part of the Thaya Terrane) intruded the base of the ophiolite sequence and has a much complex structure. Common relics of gneisses and calc silicates bring a strong evidence for an existence of an older continental crust. The age of this crust, as well as its possible relation to the ophiolites, is unknown, due to the intrusions of later granites. This probably mainly metasedimentary crust was intruded by mafic magma of dioritic composition. The Sr-Nd isotopic composition $\left({ }^{87} \mathrm{Sr} r{ }^{86} \mathrm{Sr}=0.705-0.707\right.$, $\varepsilon_{\mathrm{Nd}}=-1$ to -2 ; Finger et al. 2000b) as well as petrologic and geochemical data indicate most likely a lower crustal origin for the parental mafic magma, or a strong interaction between an ascending magma and the crust. This intrusion could have lead to a large-scale melting of the pre-existing crust and gave rise to a large S-type granite pluton of the Tetčice suite. Due to the presence of concealed diorite bodies, this type of crust is nowadays associated with a positive gravity anomaly. Another type of crust is characterized by negative gravity anomaly from geophysical point of view. Geologically it is formed by felsic, highly evolved I-type, VAG granites of the Rena suite. The protolith of this suite is unknown, because of the lack of isotopic data and absence of any geological evidence, such as enclaves.

Even less clear is the origin and tectonic position of the Hlína suite. The rocks are evidently strongly fraction- ated, but enriched in elements such as $\mathrm{Y}, \mathrm{Nb}, \mathrm{Ta}, \mathrm{U}$, and Th. Low ASI, very high $\mathrm{SiO}_{2}$, and anhydrous character would make it difficult to derive these rocks from Rena or Tetčice granites.

\subsection{Relation between the western part of the Brno Batholith and the Dyje Batholith}

Already Suess (1912) recognized some similarities between the Thaya (Dyje) and Brno batholiths. The close relation between the two was noticed more recently by Höck and Leichmann (1994), as well as Finger et al. $(1995,2000 \mathrm{a})$. The correlation between these two batholiths is not simple because of strong deformation in the western part of the Dyje Batholith. However, petrological data presented here enable us to correlate individual rock types from both batholiths.

Finger et al. (1989) distinguished four main granitoid types - Hauptgranit, Gumping, Passendorf and Gaudendorf - in the Austrian part of the Dyje Batholith.

The most widespread variety of medium-grained, lightcoloured granites and granodiorites is called Hauptgranit. This type occupies more than two thirds of the batholith's area. Finger et al. (1995) divided the Hauptgranit into two subtypes in addition. The light grey to pink biotitebearing granites of the Eggenburg/Maissau type occupy the southern part of the Batholith. The biotite-bearing, light-grey granodiorites to granites of the Pulkau/Zellendorf type are widespread in the northern part. The Gumping type corresponds to biotite-rich granodiorites to quartz monzodiorites with K-feldspar phenocrysts 2-3 $\mathrm{cm}$ across. This type is restricted to the south-western part of the Batholith. The Passendorf type, cropping out in the area between the Pulkau and Dyje valleys, is built by biotite-bearing tonalites. The term Gaudendorf type refers to fine-grained granites to granodiorites cropping out north of Eggenburg.

The division of the Dyje Batholith on the Czech territory is slightly different. The granites in the western part, approximately west of the city Znojmo, correspond mostly to the Pulkau type (Finger and Friedl 1993). The amphibole-biotite diorites and reddish leucogranites of the so-called Tasovice type (Batík 1984) crop out east of Znojmo. Diorites are often enclosed in the fine-grained biotite granodiorites, which differ from the common Pulkau type macroscopically by their finer grain and slightly higher biotite content. Likewise, the biotitebearing gneisses were found as inclusions in these finegrained granodiorites. The fine-grained granodiorites pass to the east into the coarse-grained granites of the Tasovice type.

The biotite granites to granodiorites from the Rena suite in the Brno Batholith can be well compared with 
the Pulkau/Zellendorf type from the Dyje Batholith. The common traits are leucocratic and biotite-bearing character, granitic to granodioritic composition, as well as pseudohexagonal development of the biotite crystals. Apart form petrology, similarities could be documented in whole-rock chemistry (Finger et al. 1995). The Pulkau granite is associated with the Passendorf tonalite. Tonalites were not found in the Rena suite in the Brno Batholith, however the amphibole-biotite granodiorites are characterised by relatively low modal contents of $\mathrm{K}$-feldspar. Even though the tonalites from the Dyje Batholith are more mafic compared with the granodiorites from the Brno Batholith, their gradational, spatial relation to the prevailing granites in both batholiths, and some textural traits (e.g. up to $1 \mathrm{~cm}$ long pseudohexagonal columnar biotite) suggest a close relation.

The Tetčice suite has an equivalent in the northeastern part of the Dyje Batholith in the form of inhomogeneous granodiorites with diorite and gneiss enclaves, which occur northeast of Znojmo. The abundance of enclaves, together with the petrological character (biotite granodiorites) and structural similarities (fine-grained types) support such a correlation. The diorites from the Tetčice suite are almost identical to those from the Dyje Batholith. Both are amphibole- and biotite-bearing, being enriched in $\mathrm{P}, \mathrm{Ti}$, and $\mathrm{K}_{2} \mathrm{O}$. Titanite with an ilmenite core is a typical accessory. Tonalites commonly appear at the contact with granodiorites. The whole suite cropping out northeast of Znojmo, is similar to the Tetčice suite, accompanied by a distinctive, positive gravimetric anomaly. The light, garnet-bearing, fine-grained granites which form dykes in the northern part of the Dyje Batholith (Batík and Čtyroký 1983; Leichmann 1987) could be compared, from the petrological point of view, with garnet-bearing leucogranites of the Hlina suite in the Brno Batholith.

Correlation of other two granitoid types from the Dyje Batholith is less certain. The Gaudendorf granodiorite is, according to description by Finger et al. $(1989,1995)$, similar to the granodiorites from the Tetčice suite in the Brno Batholith. Unfortunately, the published data from the Gaudendorf area do not suffice for a really detailed correlation of both types. Similarly the red Tasovice granite seems petrologically close to the red granites from the Tetčice suite.

The occurrence of the Gumping type is restricted to the Dyje Batholith. Likewise, the Sr-poor and Zr-rich Maissau type has no equivalent in the Brno Batholith. Some pink to reddish biotite granites from the Rena suite are petrologically very close to the Maissau type. But the granites from the Rena suite are enriched in $\mathrm{Sr}$ and depleted in $\mathrm{Zr}$ compared to those from the Maissau area.

Taken together, the rocks which crop out in the northern part of the Dyje Batholith - approximately north of
Pulkau river - have their equivalents in the Brno Batholith. Some types from the southern extremity of the Dyje Batholith (Gumping and Maissau) are not known from the Brno Batholith. At least the northern Dyje Batholith represents the direct southern continuation of the Western Granitoid Complex of the Brno Batholith. This Complex and Dyje Batholith differ principally from the Eastern Granitoid Complex of the Brno Batholith, though.

The Brunovistulian magmatism could be therefore classified by two principles. The petrological observations presented in this paper strongly support the division of the Brunovistulicum into two different terranes with an ophiolite belt in-between, as firstly published by Finger et al. (2000a). In this case, Thaya Terrane comprises the Brunovistulian magmatic and metamorphic rocks cropping out west of the ophiolite belt (Western Granitoid Complex of the Brno Batholith, Dyje Batholith and the concealed parts). Slavkov Terrane then contains the Brunovistulian rocks located east of the Metabasite Zone (Eastern Granitoid Complex of the Brno Batholith and concealed parts).

The second division arises more from geomorphological aspects that reflect post-Miocene erosion processes, and classify Brunovistulicum conventionally according the outcrop areas into Brno Batholith, Dyje Batholith etc.

\subsection{The position of Brunovistulicum during the Cadomian orogeny}

The discussion about the position of Brunovistulicum during the Cadomian orogeny was recently summarized by Kalvoda et al. (2008). Three different models have already been published. Pharaoh (1999) with Żelaźniewicz et al. $(1997,2001)$ argued, based on geochronological and lithological data (Glassmacher et al 1999; Gee 2001; Scarrow et 2001), for Baltica affinity of the Brunovistulicum.

More recently, Friedl et al. $(2000,2004)$ interpreted Brunovistulicum as a terrane derived from the South American part of Gondwana. Their main argument were SHRIMP zircon ages spectra with peaks at $1.2 \mathrm{Ga}, 1.5$ Ga and 1.65-1.8 Ga indicating affinity to the Grenvillian orogeny. However, these high ages were found in the socalled Bites Gneiss, which is thrusted over Brunovistulian rocks proper (Leichmann et al. 2006). Friedl (2000, 2004) considered Brunovistulicum, based on data by Finger and Steyrer (1995) with Finger et al (1995) as a part of broader tectonic unit - Moravo-Silesicum. However the Brunovistulicum is defined here more closely, and allochtonous units in the hanging wall are classified as Moravicum in accordance with Suess (1912). Main reason for the separation of Brunovistulicum from Moravicum is the presence of slightly metamorphosed Devonian marine 
sediments, which are sandwiched between Brunovistulicum and Moravicum (Jaroš and Mísař 1976; Schulmann et al. 1991). The high ages indicating the South America affinity are unknown from the Brunovistulian granites yet. However it is necessary to point out that the age of metasedimentary enclaves in Brunovistulian granites remains unconstrained.

The third model (Finger et al 1995, 1997) invoked again a Gondwanan affinity of the Brunovistulicum, and correlated this unit with the northern Africa margin. The petrological characteristics of Brunovistulicum given in this paper enable closer lithological correlation with the rocks from northern Africa margin in the Eastern Desert in Egypt.

El-Gaby (1975, 1984), El-Gaby et al (1984), Stern and Hedge (1985), Stern and Gottfried (1986), as well as Shackleton (1994) defined several intrusion events in the central and northern parts of the Eastern Desert in Egypt. The oldest one is the Abu Ziran Group, which includes, among other rock types, dismembered ophiolites with a back-arc affinity. Intrusion of tonalites to granites, and the eruption of Dokhan volcanics, manifested the younger phase. The general structure in the northern part of the Eastern Desert (ophiolites surrounded by younger granites) strongly resembles the structure observed in the Brno Batholith. Other strong evidence for a close relation between northern Gondwana and the Brno Batholith is the geochronology. The age of the ophiolites from Brno Batholith $(725 \pm 15 \mathrm{Ma}$ after Finger $2000 \mathrm{~b})$ is very close to the ages observed in the Panafrican ophiolites in the Eastern Desert (Shackleton 1994). The intrusion ages of granites and Dokhan volcanics from the Eastern Desert range between 620 and $550 \mathrm{Ma}$ (El-Gaby et al. 1984; Stern and Hedge 1985; Stern and Gottfried 1986; Shackleton 1994). These values are almost identical with the intrusion ages reported from various granites and diorites in the Brno Batholith (van Breemen et al. 1982; Dallmeyer et al. 1994).

Although it is necessary to take into account that it is difficult to compare a local geological unit of outcrop size $\sim 1200 \mathrm{~km}^{2}$ with a huge craton several $10000 \mathrm{~km}^{2}$ in size, some important analogies in the geological structure and geochronology between the Brno Batholith and northern Gondwana margin could be found.

\section{Conclusions}

The Brno Batholith, and consequently whole Brunovistulicum, consists of three independent magmatic complexes. They are from West to East: the Western Granitoid Complex (part of the Thaya Terrane), the central Ophiolite Belt (formerly termed Metabasite Zone or Central Basic Belt), and the Eastern Granitoid Complex (part of the Slavkov Terrane). These complexes differ in petrology, chemistry, and post-magmatic evolution.

Three suites of magmatic rocks - Rena, Tetčice and Hlína - were distinguished in the Western Granitoid Complex. The amphibole-biotite granodiorites to biotite granites of the Rena suite represent differentiated I-type granitoids with a strong volcanic-arc affinity. The biotite-bearing, Stype granodiorites of the Tetčice suite originated most likely via partial anatexis of metasedimentary crust. It could have been a consequence of elevated heat flow, induced by an intrusion of dioritic magma at depth, followed by mixing between the primary mafic and secondary granitic melts. The granodiorites of both suites have undergone local late-stage alteration manifested by strong replacement of plagioclase by white mica and albite, and the formation of epidote, carbonate, and palygorskite veinlets. Dykes, or small bodies of highly differentiated I- to A-type, garnetbearing granites of the Hlína suite with a strong withinplate affinity, cut through both suites. All three suites have direct equivalents in the Dyje Batholith, which represents a southern continuation of the Brno Batholith.

The ophiolites comprise a full sequence including ultramafic and plutonic rocks, basaltic volcanics, ranging even to acidic composition. Based on the lithology and whole-rock geochemistry of the basalts, the ophiolitic complex can be interpreted, most likely, as supra-subduction zone related.

Our petrological data support the idea of Finger et al. (2000a), who interpreted the Brunovistulicum as an arc (Slavkov Terrane) - continent (Thaya Terrane) collisional zone with relics of ocean floor (Ophiolite Belt) in-between.

The broad fit in the geological structure (older ophiolites surrounded by younger granitoids) and geochronology between Brunovistulicum and the northern part of the Eastern Desert in Egypt may favour a close relation of Brunovistulicum to the northern Gondwana margin during the Panafrican orogeny. Nevertheless, alternative views, searching primary position of Brunovistulicum at South America margin or in an orogen-rimmed Baltica could not be excluded yet.

Acknowledgements: The research was supported by the project MSM 0021622416. The authors thank E. Jelínek and V. Janoušek for editorial handling and two anonymous reviewers for their comments and suggestions.

\section{References}

BAKER F (ed) (1979) Trondhjemites, Dacites and Related Rocks. Elsevier, Amsterdam, pp 1-283

BARBARIN B (1996) Genesis of two main types of peraluminous granitoids. Geology 4: 295-298 
Barton M, SidLe SC (1993) Petrological and geochemical evidence for granitoid formation: the Waldoboro Pluton Complex, Maine. J Petrol 35: 1241-1273

ВАті́к P (1984) Geological structure of Moravicum between Bíteš gneiss and Dyje Batholith. Věst Ústř Úst geol 59: 321-330 (in Czech)

BAтí P, C̆түROKÝ P (1983) Explanations to the geological map 1: 25000 sheet Šatov 34-131. Czech Geological Survey, Prague (in Czech)

Best MG, Christiansen (2001) Igneous Petrology. Blackwell Science, Malden, pp 1-458

Clarke DB, (1981) The mineralogy of peraluminous granites: a review. Canad Mineral 19: 3-17

Champion DC, Chappell BW (1992) Petrogenesis of felsic I-type granites: an example from northern Queensland. Trans Roy Soc Edinb, Earth Sci 83: 115-126

Chappell BW, White AJR (1992) I- and S-type granites in the Lachlan Fold Belt. Trans Roy Soc Edinb, Earth Sci 83: 1-26

Dallmeyer DR, Fritz H, Neubauer, F, Urban M (1994): ${ }^{40} \mathrm{Ar} /{ }^{39} \mathrm{Ar}$ mineral age controls on the tectonic evolution of the southeastern Bohemian Massif. Pre-alpine Crust in Austria, Excursion guide 'Geology of the Moravian Zone', Krems, pp 14-22

Deer WA, Howie RA, Zussman J (1992) An Introduction to the Rock-Forming Minerals. Longman, Essex, pp 1-696

DiDiER J (1987) Contribution of enclave studies to the understanding of origin and evolution of granitic magmas. Geol Rundsch 76: 41-51

Dirnhofer M (1996): Zur Geologie und Petrographie des kristallinen Untegrundes der Molassezone in Niederösterreich. Unpublished MSc thesis, University of Salzburg, pp 1-157

Dudek A (1980) The crystalline basement block of the Outer Carpathians in Moravia: Brunovistulicum. Rozpr Čs Akad Věd, Ř mat prír Věd, 90: 3-85

EL-Gaby S (1975) Petrochemistry and geochemistry of some Granites from Egypt. Neu Jb Mineral, Abh 124: 147-189

EL-GABy S (1984) Architecture of the Egyptian Basement Complex. Proc $5^{\text {th }}$ Int Conf on Basement Tectonics, Cairo, pp 1-7

EL-Gaby S, El-Nady O, Khudeir A (1984) Tectonic evolution of the basement complex in the Central Eastern Desert of Egypt. Geol Rundsch 73: 1019-1036

Finger F, Steyrer HP (1995) A tectonic model for the eastern Variscides: indications from a chemical study of amphibolites in the southeastern Bohemian Massif. Geol Carpath 46: 137-150

Finger F, Friedl G (1993): Bericht 1992 über petrographische Untersungen im Moravikum auf Blatt 9 Retz. Jb Geol. B-A 136: 637-638

Finger F, PIN C (1997) Arc-type crustal zoning in the Brunovistulicum, eastern Czech Republic: a trace of the late Proterozoic Euro-Gondwana margin. J Czech Geol Soc 42: 53

Finger F, Frasl, G, Höck V, STeyrer HP (1989) The granitoids of the Moravian Zone of northeast Austria: product of a Cadomian active continental margin? Precambr Res 45: 235-245

Finger F, Frasl G, Dudek A, Jelínek E, Thöni M (1995) Cadomian plutonism in the Moravo-Silesian basement. In: Dallmeyer RD, Franke W, Weber KP (eds) Tectonostratigraphic Evolution of the Central and Eastern European Orogens. Springer-Verlag, Berlin, pp 495-507

Finger F, Hanžl P, Pin C, Quadt A, Steyrer HP (2000a) The Brunovistulicum: Avalonian Precambrian at the eastern end of the Variscides. In: Franke W, Altherr R, HaAK W, Oncken O, TANNER D (eds) Orogenic Processes: Quantification and Modelling in the Variscan Belt of Central Europe. Geological Society London Special Publication 179: pp 103-112

Finger F, Tichomirowa M, Pin C, Hanžl P (2000b) Relics of an early-Panafrican metabasite-metarhyolite formation in the Brno Massif, Moravia, Czech Republic. Int J Earth Sci 89: 328-335

FišERA M, PATOČKA F (1989) Geochemistry of Variscan blastomylonites of the Vidly pod Pradědem locality, the Hrubý Jeseník Mts.: paleotectonic implications. Věst Ústř Úst geol 64: 301-312

FRASL G, (1963): Die mikroskopische Untersuchung der akcesorischen Zirkone als eine Routinearbeit des Kristallingeologen. Jb Geol B-A 106: 405-428

Friedl G, Finger F, McNaughton NJ, Fletcher IR (2000) Deducing the ancestry of terranes: SHRIMP evidence for South America-derived Gondwana fragments in central Europe. Geology 28: 1035-1038

Friedl G, Finger F, Paquette JL, von Quadt A, McNaughton NJ, Fletcher IR (2004) Pre-Variscan geological events in the Austrian part of the Bohemian Massif deduced from U-Pb zircon ages. Int J Earth Sci 98: 802-823

Garcia D, Pascal, M. L, Roux J (1996) Hydrothermal replacement of feldspars in igneous enclaves of the Valey granite and the genesis of myrmekites. Eur J Miner 8: 703-717

GEE D (2001) Overview of the Timanide Orogen along the Eastern Margin of the East European Craton. Joint meeting of EUROPROBE, TESZ, TIMPEBAR, URALIDES \& SW Iberia Projects, Ankara 30 September-2 October, 2001. Abstracts, pp 19-20

Geofyzika (2000): Gravimetrical map of the Czech Republic, 1: 500 000. Geofyzika Ltd., Brno

Glassmacher UA, Reynold P, Alekseyev A, Puchkov VN, TAYlor K, Gorozhanin V, Walter R (1999) ${ }^{40} \mathrm{Ar} /{ }^{39} \mathrm{Ar}$ thermochronology west of the Main Uralian fault, southern Urals, Russia. Geol Rundsch 87: 515-525

Goodwin AM, (1996) Principles of Precambrian Geology. Academic Press, London, pp 1-280 
Gregerová M (1982) The ultramafic rocks of the Brno Massif. Folia Fac Sci Nat Univ Purk 21: 3-34 (in Russian)

HANŽL P (1994) The correlation between the Nectava gneisses and granodiorites of the northern part of the Brno Massif. Věst Czech Geol Úst 69: 73-80

HanžL P, Melichar R (1997): Brno Massif: a section through the active continental margin or composed terrane? Krystalinikum 23: 33-58

Höck V (1975) Mineralzonen in Metapeliten und Metapsamiten der Moravischen Zone in Niederöstrreich. Mitt Österr Geol Ges 66-67: 49-60

Höck V, Leichmann J (1994) Exkursion C: Das Moravikum der Thayakuppel. Mitt Österr Miner Ges 139: 407-427

JARoš J, Mísař Z (1976) Nomenclature of the tectonic and lithostratigraphic units in the Moravian Svratka dome. Věst Ústř úst geol 51: 113-122

Jelínek E, Dudek A (1993) Geochemistry of subsurface Precambrian plutonic rocks from the Brunovistulian complex in the Bohemian Massif, Czechoslovakia. Precambr Res 62: 103-125

JANOUŠEK V, HANŽL P (2000) Nd isotopic composition of metabasalts from the metabazite Zone, Brno Massif - geochronological and genetic implications. In: Abstracts of the Conference Moravskoslezké Paleozoikum, February 3, 2000, Brno, pp 8 (in Czech)

Kalvoda J, Bábek O, FatKa O, Leichmann J, Melichar R, Nehyba S, ŠpačEk P (2008) Brunovistulian Terrane (Bohemian Massif, Central Europe) from late Proterozoic to late Paleozoic: an overview. Int J Earth Sci 97: 497-518

Leichmann J (1987) Petrology of the western part of the Dyje Massif. Unpublished MSc thesis. University of J. E. Purkyně, Brno, pp 1-66 (in Czech)

Leichmann J (1994) Trondhjemites of the Brno Massif. Geol výzk Mor a Slez v r 1993: 82-85 (in Czech)

Leichmann J (1996) Geologie und Petrologie des Brünner Massivs. Unpublished PhD thesis, University of Salzburg, pp 1-118

Leichmann J, Novák M, Sulovský, P (1999) Peraluminous whole-rock chemistry versus peralkaline mineralogy of highly fractionated, garnet-bearing granites from the Brno Batholith. Ber Deutsch Miner Ges 1: 144

Leichmann J, Kapinus A, PivničKa L, Weber R (2006) Želetice Group: very low-grade Palaeozoic sequence at the base of Moravicum, Czech Republic. J Czech Geol Soc 51: 189-199

Le Maitre RW (ed) (1989) A Classification of Igneous Rocks and Glossary of Terms. Blackwell Scientific Publications, Oxford, pp 1-193

Melichar R (1995) Tectonic significance of the Boskovice Furrow. Geol Výzk Mor Slez 1994: 64-66 (in Czech)

Mittrenga P, Rejl L (1993) Brno Massif. In: Přichystal A, Obstová V, Suk M (eds) Geology of Moravia and Silesia. Moravian museum, Brno, pp 1-168
Mittrenga P, Weiss J, Rejl L (1976) New results about the geological structure of the southern part of the Brno Massif. Výzk Práce Ústř Úst Geol 13: 33-39 (in Czech)

NovÁk M, Filip J (2002) Ferroan magnesioaxinite from hydrothermal veins at Lažany, Brno Batholith, Czech Republic. Neu Jb Miner, Mh 7: 385-399

Pearce JA, Cann JR (1973) Tectonic setting of basic volcanic rocks determined using trace element analysis. Earth Planet Sci Lett 19: 290-300

Pearce JA, Harris NBW, Tindle AG (1984) Trace element discriminations diagrams for the tectonic interpretation of the granitic rocks. J Petrol 28: 956-983

Pharaoh TC (1999) Palaeozoic terranes and their lithospheric boundaries within the Trans-European Suture Zone (TESZ): a review. Tectonophysics 314: 17-41

Pitcher WS (1997) The Nature and Origin of Granite. Chapman \& Hall, London, pp 1-387

PřICHYSTAL A (1999) K-Ar age determination of a basaltic dyke from Želešice (Brno Massif). Geol Výzk Mor Slez 1993: 60-62 (in Czech)

PuPIN JP (1980) Zircon and granite petrology. Contrib Mineral Petrol 73: 207-220

PuPIN JP (1985) Magmatic zoning of Hercynian granitoids in France based on zircon morphology. Schweiz Mineral Petrogr Mitt 65: 29-56

Riegler G (2000) Chemischen und Th-U-Pb Modelalter akzessorischen Monazite aus kristallinen Bohrkernen des Weinviertels und ihre Bedeutung für das Verständnis der geologischen Situation am Ostrand der Böhmische Masse. Unpublished MSc thesis, University of Salzburg, pp $1-72$

Scarrow JH, Pease V, Fleutelot C, Dushin V (2001) The late Neoproterozoic Enganepe ophiolite, Polar Urals, Russia: an extension of the Cadomian arc? Precambr Res 110: 255-275

Shackleton RM (1994) Review of the Late Proterozoic sutures, ophiolitic mélanges and tectonics of the eastern Egypt and north-east Sudan. Geol Rundsch 83: 537-547

Schulmann K, Ledru P, Autran A, Melka R, Lardeaux JM, Urban M, LobKowicz M (1991) Evolution of nappes in the eastern margin of the Bohemian Massif: a kinematic interpretation. Geol Rundsch 80: 73-92

SKÁCELOVÁ D, WeISS J (1978) A model of the development of the Brno Massif based on geophysical data (in Czech). Čas Mineral Geol 23: 409-415

Stern RJ, Gottfried D (1986) Petrogenesis of a late Precambrian (575-600 Ma) bimodal suite in Northeast Africa. Contrib Mineral Petrol 92: 492-501

Stern RJ, Hedge CE (1985) Geochronologic and isotopic constrains on Late Precambrian crustal evolution in the Eastern Desert of Egypt. Amer J Sci 285: 97-127

Suess FE (1903) Bau und Bild der Böhmischem Masse. Tempsky, Wien. pp 1-290 
Suess FE (1912) Die Moravischen Fenster und ihre Beziehung zum Grundgebirge des Hohen Gesenke. Denkrsch K Akad Wiss, math Naturwiss, pp 1-91

SulOvSKÝ P (1975): The accessory minerals from the Metabasite Zone of the Brno Massif. Unpublished MSc thesis, University of J. E. Purkyně, Brno, pp 1-78

ŠMEJKAL V (1964): The absolute age of some igneous and metamorphic rocks determined using K-Ar method. Věst ÚÚG 35: 441-449 (in Czech)

Štelcl J, Weiss J (eds) (1986) The Brno Massif. University of J. E. Purkyně, Brno, pp 1-255 (in Czech)

van Breemen O, Aftalion A, Bowes D, Dudek A, Mísař Z, Povondra P, VRÁNA S (1982) Geochronological studies of the Bohemian Massif, Czechoslovakia, and their significance in the evolution of Central Europe. Trans Roy Soc Edinb, Earth Sci 73: 89-108.
Williamson BJ, Downes H, Thirlwall MF (1992) The relationship between crustal magmatic underplating and granite genesis: an example from the Velay granite complex, Massif Central, France. Trans Roy Soc Edinb, Earth Sci 83: 235-245

ŻElaźniewicz A, BuŁa Z, Jachowicz M, ŻABA J (1997) Crystalline basement SW of the Trans-European Suture Zone in Poland: Neoproterozoic Cadomian orogen. Terra Nostra 11: 167-171

ŻElaźniewicz A, Seghedi A, Jachowicz M, Bobinski W, BuŁA Z, CwoJdZINSKI S (2001) U-Pb SHRIMP data confirm the presence of Vendian foreland flysch basin next to the East European Craton. Joint meeting of EUROPROBE, TESZ, TIMPEBAR, URALIDES \& SW Iberia Projects, Ankara 30 September-2 October, 2001. Abstracts vol, pp 98-100 